\title{
Phosphoinositide 3-Kinase Gamma Contributes to Neuroinflammation in a Rat Model of Surgical Brain Injury
}

\author{
Lei Huang, ${ }^{1,2}$ Prativa Sherchan, ${ }^{2}$ Yuechun Wang, ${ }^{2,4}$ Cesar Reis, ${ }^{1}$ Richard L. Applegate II, ${ }^{1}$ Jiping Tang, ${ }^{2}$ \\ and John H. Zhang ${ }^{1,2,3}$ \\ Departments of ${ }^{1}$ Anesthesiology, ${ }^{2}$ Physiology and Pharmacology, and ${ }^{3}$ Neurosurgery, Loma Linda University, Loma Linda, California 92354, and \\ ${ }^{4}$ Department of Physiology, School of Medicine, University of Jinan, Guangzhou 510632, China
}

\begin{abstract}
Neuroinflammation plays an important role in the pathophysiology of surgical brain injury (SBI). Phosphoinositide 3-kinase gamma $(\mathrm{PI} 3 \mathrm{~K} \gamma)$, predominately expressed in immune and endothelial cells, activates multiple inflammatory responses. In the present study, we investigated the role of PI3K $\gamma$ and PI3K $\gamma$-activated phosphodiesterase 3B (PDE3B) in neuroinflammation in a rat model of SBI. One hundred and fifty-two male Sprague Dawley rats (weight 280-350 g) were subjected to a partial right frontal lobe corticotomy model of SBI. A PI3K $\gamma$ pharmacological inhibitor (AS252424 or AS605240) was administered intraperitoneally. PI3K $\gamma$ siRNA, human recombinant active-PI3K $\gamma$ protein, or human recombinant active-PDE3B protein were administered intracerebroventricularly. Post-SBI assessments included neurobehavioral tests, brain water content, Western blot, and immunohistochemistry. Endogenous PI3K $\gamma$ levels were increased within peri-resection brain tissues after SBI, accompanied by increased brain water content and neurological functional deficits. There was a trend toward increased endogenous PDE3B phosphorylation after SBI. The selective PI3K $\gamma$ inhibitors AS252424 and AS605240 reduced brain water content surrounding corticotomy and improved neurological function after SBI. SBI increased and PI3K $\gamma$ inhibitor decreased levels of myeloperoxidase, cluster of differentiation 3, mast cell degranulation, E-selectin, and IL-1 in peri-resection brain tissues. Direct administration of human recombinant active-PI3K $\gamma$ protein and active-PDE3B protein countered the protective effect of AS252424. PI3K $\gamma$ siRNA reduced PI3K $\gamma$ levels, decreased brain water content within peri-resection brain tissues, and improved neurological function after SBI. Collectively, our findings suggest that PI3K $\gamma$ contributed to neuroinflammation after SBI. The use of selective PI3K $\gamma$ inhibitors may be a novel approach to ameliorating SBI via their anti-inflammation effects.
\end{abstract}

Key words: blood-brain barrier; brain edema; inflammation; neurosurgery; PDE3B; PI3K $\gamma$

Significance Statement

Life-saving or elective neurosurgeries often involve unavoidable damages to neighboring, nondiseased brain tissues. Such surgical brain injury (SBI) is attributable exclusively to the neurosurgical procedure itself and may cause postoperative complications that exacerbate neurological function. Although the importance of this medical problem is fully acknowledged, intraoperative administration of adjunctive treatment such as steroids and mannitol to patients undergoing neurosurgery appear not to be efficient remedies for SBI. To date, the issue of perioperative neuroprotection specifically against SBI has not been well studied. Using a clinically relevant rat model of SBI, we are exploring a new neuroprotective strategy targeting phosphoinositide 3-kinase gamma $(\mathrm{PI} 3 \mathrm{~K} \gamma)$. PI3K $\gamma$ activates multiple inflammatory responses. By attenuating neuroinflammation, selective PI3K $\gamma$ inhibition would limit postoperative complications and benefit neurological outcomes.

\section{Introduction}

Surgical brain injury (SBI) that is attributable exclusively to the neurosurgical procedure itself may cause postoperative complications such as brain edema, ischemia, and intracranial

\footnotetext{
Received Feb. 9, 2015; revised May 26, 2015; accepted June 2, 2015.

Author contributions: L.H. and J.H.Z. designed research; L.H.,P.S.,Y.W., and C.R. performed research;L.H., R.L.A., and J.T. analyzed data; L.H., R.L.A., and J.H.Z. wrote the paper.

This work was supported by the National Institutes of Health (Grants NS084921, NS082184, and NS43338 to J.H.Z.).

The authors declare no competing financial interests.
}

hematoma, worsening neurological and behavioral outcomes (Manninen et al., 1999; Solaroglu et al., 2004). We demonstrated previously that neuroinflammation played important roles in the pathophysiology of SBI, characterized by activation of resident immune cells, leukocyte infiltration, and release of inflammatory

Correspondence should be addressed to Dr. John H. Zhang, Departments of Anesthesiology and Physiology, Loma Linda University School of Medicine, Risley Hall, Room 219, 11041 Campus Street, Loma Linda, CA 92354. E-mail: Johnzhang3910@yahoo.com.

DOI:10.1523/JNEUROSCI.0546-15.2015

Copyright $\odot 2015$ the authors $\quad 0270-6474 / 15 / 3510390-12 \$ 15.00 / 0$ 
Experiment 1: Time course

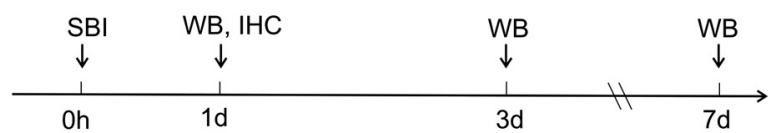

Group: Sham, SBI-1d, SBI-3d, SBI-7d

Experiment 2: The detrimental role of $\mathrm{PI} 3 \mathrm{~K} y$ in SBI

A AS 252424

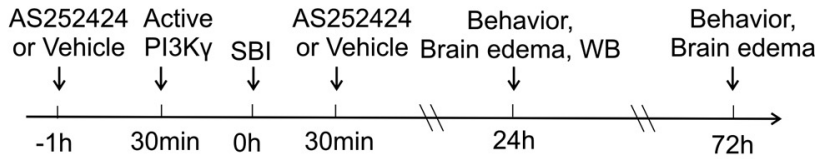

Group: Sham, SBI+Vehicle, SBI+AS252424 3mg/kg, SBI+AS252424 10mg/kg, SBI+AS252424 10mg/kg+Active-PI3Ky (200ng)

B PI3Ky-PDE3B signaling

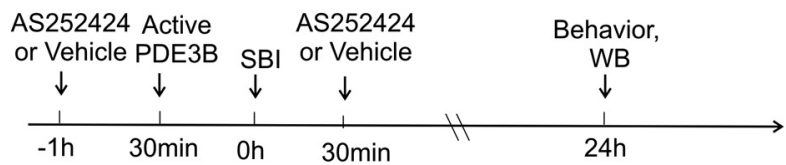

Group: Sham, SBI+Vehicle, SBI+AS252424 10mg/kg, SBI+AS252424 10mg/kg+Active-PDE3B (100ng)

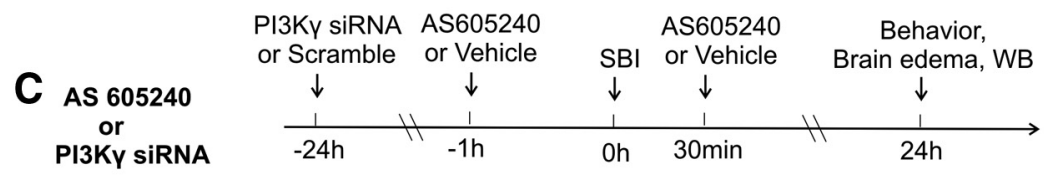

Group: Sham, SBI+Vehicle, SBI+AS605240 10mg/kg, SBI+Scramble siRNA, SBI+PI3Ky siRNA

Figure 1. Experimental design and animal groups. WB, Western blot; IHC, immunohistochemistry.

Table 1. Summary of experimental groups, interventions, and sample sizes

\begin{tabular}{|c|c|c|}
\hline Experimental group & Treatment & Animal no. \\
\hline Sham & None & 13 \\
\hline SBI + vehicle & Vehicle, i.p. & 32 \\
\hline $\mathrm{SBI}+\mathrm{AS} 2524243 \mathrm{mg} / \mathrm{kg}$ & AS252424 3 mg/kg, i.p. & 8 \\
\hline $\mathrm{SBI}+\mathrm{AS} 25242410 \mathrm{mg} / \mathrm{kg}$ & AS252424 10 mg/kg, i.p. & 21 \\
\hline $\begin{array}{l}\mathrm{SBI}+\mathrm{AS} 25242410 \mathrm{mg} / \mathrm{kg}+ \\
\text { human recombinant } \\
\text { active-PI3K } \gamma\end{array}$ & $\begin{array}{l}\text { AS252424 } 10 \text { mg/kg, i.p.; } \\
\text { human recombinant active-PI3K } \gamma \\
200 \text { ng, i.c.v. }\end{array}$ & 13 \\
\hline $\begin{array}{l}\mathrm{SBI}+\mathrm{AS} 25242410 \mathrm{mg} / \mathrm{kg}+ \\
\text { human recombinant } \\
\text { active-PDE3B }\end{array}$ & $\begin{array}{l}\text { AS252424 } 10 \text { mg/kg, i.p.; } \\
\text { human recombinant active-PDE3B } \\
100 \text { ng, i.c.v. }\end{array}$ & 6 \\
\hline $\mathrm{SBI}+\mathrm{AS} 60524010 \mathrm{mg} / \mathrm{kg}$ & AS605240 10 mg/kg, i.p. & 7 \\
\hline SBI + scramble siRNA & Scramble siRNA, i.c.v. & 15 \\
\hline SBI + PI3K p110 $\gamma$ siRNA & PI3K p110 $\gamma$ siRNA 500 pmol, i.c.v. & 15 \\
\hline
\end{tabular}

i.p., Intraperitoneally; i.c.v., intracerebroventricularly.

mediators within brain tissues adjacent to the resection (Lo et al., 2007; Hyong et al., 2008; Ayer et al., 2012). Therapeutic strategies targeting neuroinflammation may limit postoperative complications and thus enable a more aggressive surgical approach.

Phosphoinositide 3-kinase gamma (PI3K $\gamma$ ), a PI3K class IB isoform, controls a wide range of immune cell activities and vascular functions (Hirsch et al., 2000; Hirsch et al., 2006). Specifically with regard to inflammation, the predominant expression of PI3K $\gamma$ in leukocytes and endothelial cells participated in leukocyte chemotaxis and neutrophil oxidative burst (Hirsch et al., 2000; Puri et al., 2005; Hirsch et al., 2006; Rückle et al., 2006; Ghigo et al., 2010), T-cell proliferation and cytokine production (Hirsch et al., 2000; Sasaki et al., 2000; Smith et al., 2007; Thomas et al., 2008), and mast cell activation and degranulation (Hirsch et al., 2000; Laffargue et al., 2002). Emerging evidence has shown that gene ablation of PI3K $\gamma$ or pharmacological inhibition of $\mathrm{PI} 3 \mathrm{~K} \gamma$ exerted protective effects in preclinical models of systemic inflammation including systemic lupus, rheumatoid arthritis, lung disease, sepsis, and colitis (Barber et al., 2005; Camps et al., 2005; Martin et al., 2010; van Dop et al., 2010; Kim et al., 2012). Recently, several studies identified the detrimental effects of $\mathrm{PI} 3 \mathrm{~K} \gamma$ in neuroinflammation in brain ischemic injury and Alzheimer's disease (Jin et al., 2010b; Passos et al., 2010; Jin et al., 2011). Moreover, PI3K $\gamma$ has been shown to activate phosphodiesterase 3 (PDE3B), which suppresses cyclic adenosine monophosphate (cAMP) signaling (Patrucco et al., 2004; Perino et al., 2011; Schmidt et al., 2013).

In this study, we investigated the roles of PI3K $\gamma$ in neuroinflammation in a rat model of SBI by PI3K $\gamma$ pharmacological inhibition, by human recombinant active-PI3K $\gamma$ protein and active-PDE3B protein to counter the effect of the PI3K $\gamma$ inhibitor, and by PI3K $\gamma$ siRNA-mediated PI3K $\gamma$ knock-down.

\section{Materials and Methods}

Animals. All procedures in this study were approved by the Institutional Animal Care and Use Committee at Loma Linda University and complied with the National Institutes of Health's Guide for the Care and Use of Laboratory Animals. Adult male Sprague Dawley rats (weight 280-350 g) were housed in a vivarium for a minimum of $3 \mathrm{~d}$ before surgery with a $12 \mathrm{~h}$ light/dark cycle and ad libitum access to food and water.

Experimental design. Experiments were performed in a rat model of SBI, as shown in Figure 1. A total of 152 rats were used.

Experiment 1 was to characterize the time course of endogenous changes in four PI3K isoforms, including $\mathrm{PI} 3 \mathrm{~K} \alpha, \mathrm{PI} 3 \mathrm{~K} \beta, \mathrm{PI} 3 \mathrm{~K} \gamma$, and $\mathrm{PI} 3 \mathrm{~K} \delta$, as well as total/phosphorylated PDE3B levels within residual frontal lobe brain tissues at 1,3 , and $7 \mathrm{~d}$ after SBI. Twenty rats were randomized into four groups: sham, SBI-1d, SBI-3d, and SBI-7d ( $n=$ 5 /group). The additional two rats in the SBI-1d group were used for immunohistochemistry. 
A

$110 \mathrm{kDa}$
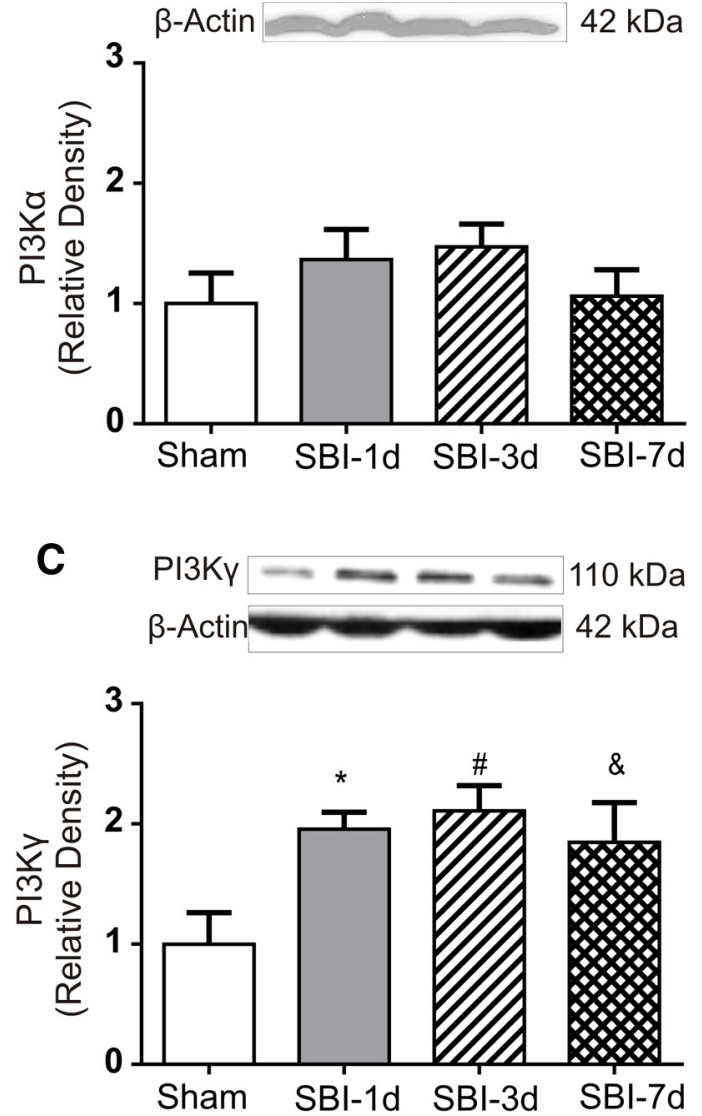

B
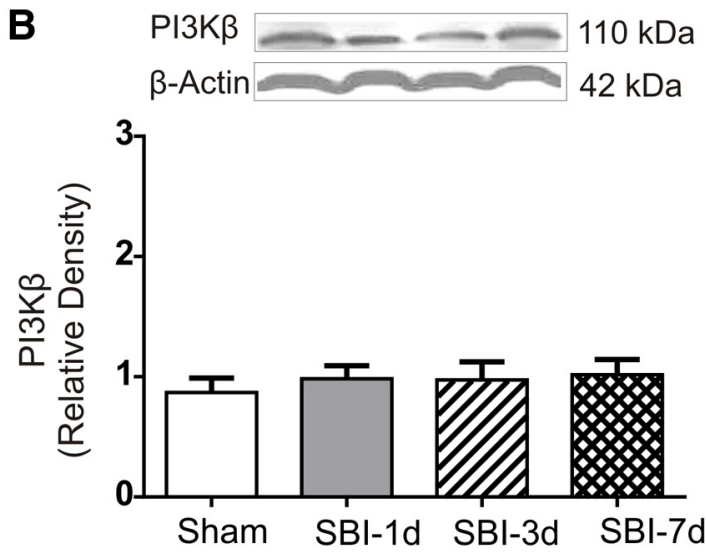

D
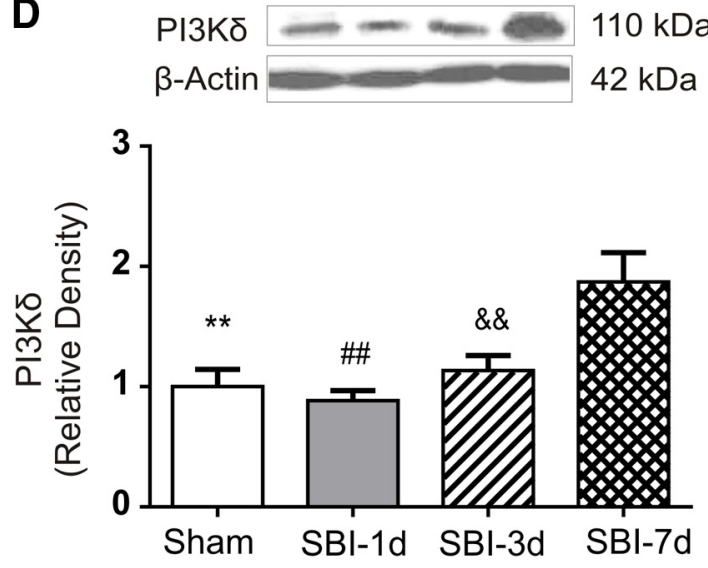

E

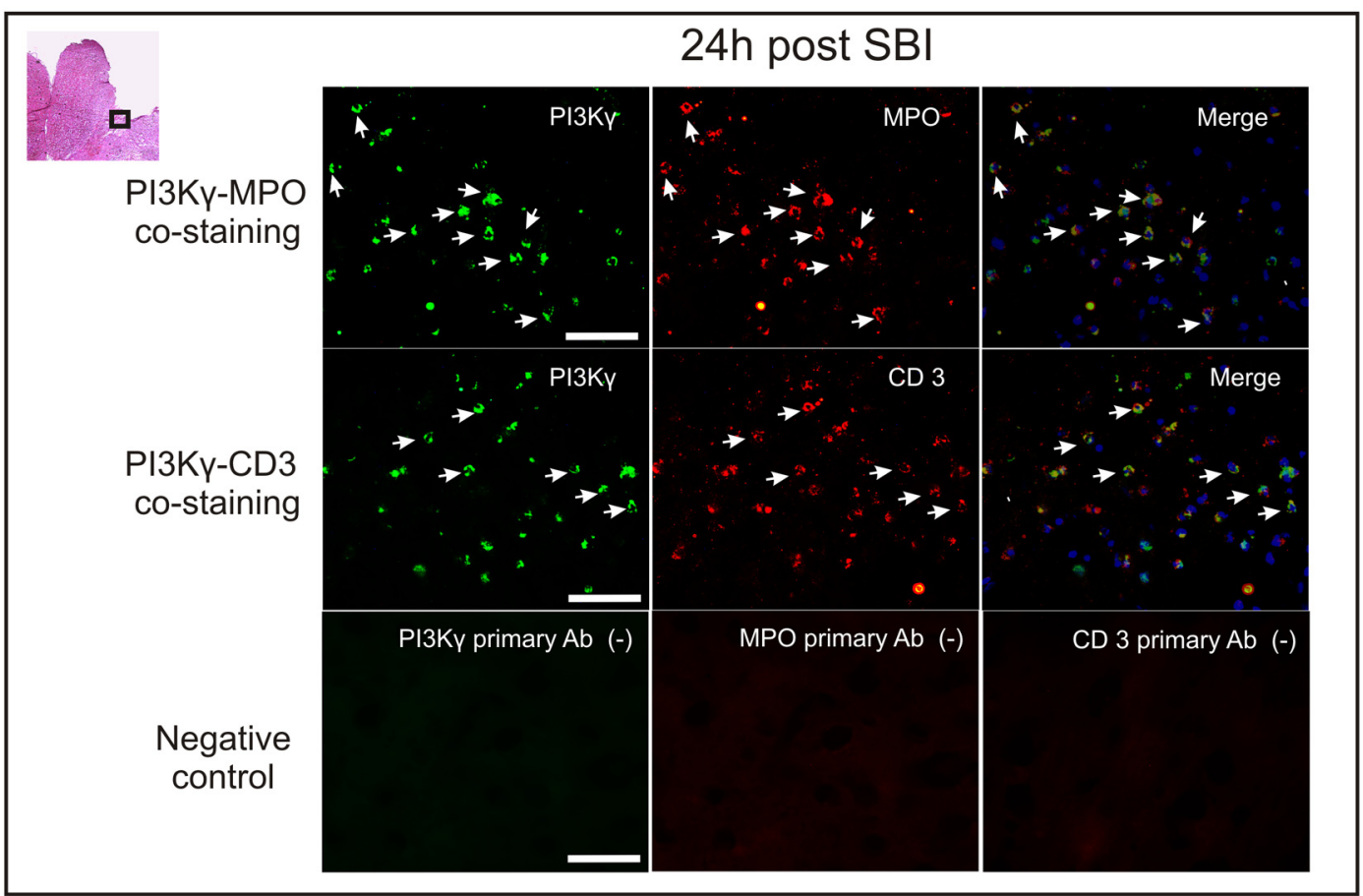

Figure 2. Time course of PI3K isoforms changes within peri-resection brain tissues after SBI. Although there were no significant changes in PI3K $\alpha(p=0.419)$ and PI3K $\beta$ ( $p=0.856) 0$ ver $7 \mathrm{~d}$ $(\boldsymbol{A}, \boldsymbol{B}), \mathrm{PI} 3 \mathrm{~K} \gamma$ levels increased at 1, 3, and $7 \mathrm{~d}$ after SBI (C) and PI3K $\delta$ level increased $7 \mathrm{~d}$ after SBI (D) ( $n=5 /$ group). One-way ANOVA followed by Student-Newman-Keuls post hoc tests were used.

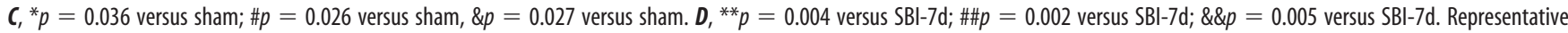
immunohistochemistry microphotographs of PI3K $\gamma$ staining with MPO or CD3 revealed that PI3K $\gamma$ expression was colocalized with immune cells including infiltrated neutrophils (MPO) and T-cells (CD 3) $1 \mathrm{~d}$ after SBI (E). Negative control staining without the primary antibody (Ab) did not show detectable labeling (E). Arrows indicate cells with positive staining. Scale bar, $50 \mu \mathrm{m}$. 
Experiment 2 was to evaluate the detrimental role of PI3K $\gamma$ in the pathophysiology of SBI as follows. First, we tested the effect of the selective PI3K $\gamma$ inhibitor AS252424. Seventy-six rats were used in the following groups: sham $(n=13)$, SBI + vehicle $(n=21)$, SBI + AS252424 3 $\mathrm{mg} / \mathrm{kg}(n=8), \mathrm{SBI}+\mathrm{AS} 25242410 \mathrm{mg} / \mathrm{kg}(n=21)$, and SBI + AS252424 $10 \mathrm{mg} / \mathrm{kg}+$ human recombinant active-PI3K $\gamma(n=13)$. AS252424 was dissolved in $24 \%$ dimethyl sulfoxide/ $0.5 \%$ carboxymethylcellulose (CMC) $/ 0.25 \%$ Tween 20 saline with final concentration of $4.2 \mathrm{mg} / \mathrm{ml}$. The inhibitor or same volume of vehicle was injected intraperitoneally $1 \mathrm{~h}$ before and $30 \mathrm{~min}$ after brain resection. Human recombinant activePI3K $\gamma$ protein ( $200 \mathrm{ng}, 2 \mu \mathrm{l}$; SignalChem) was administered by intracerebroventricular injection $30 \mathrm{~min}$ before SBI. Second, we investigated whether the effects of the PI3K $\gamma$ inhibitor are mediated through repression of PI3K $\gamma$-PDE3B signaling. An additional group of SBI + AS252424 + human recombinant active PDE3B $(n=6)$ was added. Human recombinant active-PDE3B (100 ng, $2 \mu$; SignalChem) was administered intracerebroventricularly $30 \mathrm{~min}$ before SBI. Third, we tested the protective effects of PI $3 \mathrm{~K} \gamma$ inhibition using another selective $\mathrm{PI} 3 \mathrm{~K} \gamma$ inhibitor, AS605240, or siRNA-mediated PI3K $\gamma$ knock-out. Forty-eight rats in four additional groups were added: SBI + vehicle $(n=11)$, SBI + AS605240 $10 \mathrm{mg} / \mathrm{kg}(n=7), \mathrm{SBI}+$ scramble siRNA $(n=15)$, and SBI + PI3K p110 $\gamma$ siRNA $(n=15)$. AS605240 was dissolved in $0.5 \% \mathrm{CMC} / 0.25 \%$ Tween 20 saline with a final concentration of $5 \mathrm{mg} / \mathrm{ml}$. The inhibitor or same volume of vehicle was injected intraperitoneally $1 \mathrm{~h}$ before and 30 min after brain resection. The 500 pmol of p110 $\gamma$ siRNA (Accell SMART pool; Thermo Fisher Scientific) was dissolved in $2 \mu \mathrm{l}$ of sterilized water and injected intracerebroventricularly $24 \mathrm{~h}$ before SBI. The same volume of scramble siRNA (siGENOME nontargeting siRNA Thermo Fisher Scientific) was administered as a control. The dosages of AS252424 and AS605240 were determined according to previous studies (Pomel et al., 2006; Kobayashi et al., 2011). Treatment and sample size in all experiment groups are summarized in Table 1.

SBI model. Anesthesia was induced via induction chamber with $4 \%$ isoflurane and maintained with $2.5 \%$ via nasal mask. Temperature was controlled throughout surgery with thermal heat lamps. Rats were placed prone in a stereotactic frame. SBI was induced as described previously (Yamaguchi et al., 2007). Briefly, a midline incision was made and the periosteum was reflected to expose the bregma and the right frontal skull. A $5 \times 5 \mathrm{~mm}$ square craniotomy with the lower left corner at the bregma was made by a microdrill on the right frontal skull. Care was taken to keep the dura intact. For SBI animals, the dura was incised and a dissection of brain tissue was made to create a partial right frontal lobectomy. The margins of the brain tissue cut were $2 \mathrm{~mm}$ lateral to the sagittal suture and $1 \mathrm{~mm}$ proximal to the coronal suture, with the depth extending to the base of the skull. Intraoperative packing and normal saline irrigation was used until hemostasis was obtained. Afterward, the incision was closed with sutures. Sham surgeries underwent the same surgical procedure without craniotomy and brain resection. Vital signs were monitored throughout surgery and recovery. Twenty-four or $72 \mathrm{~h}$ after surgery, neurological functions were assessed, after which time the animals were killed for brain water content measurement, Western blot, or immunohistochemistry assay as described below.

Intracerebroventricular injection. As described previously (Chen et al., 2013, Liu et al., 2007), rats were anesthetized with isoflurane (4\% induction, $2.5 \%$ maintenance) and mounted on a stereotaxic frame. The needle of a $10 \mu$ l Hamilton syringe was inserted through a burr hole perforated through the skull into the right lateral ventricle using the following coordinates relative to bregma: $1.5 \mathrm{~mm}$ posterior, $1.0 \mathrm{~mm}$ lateral, and $3.2 \mathrm{~mm}$ below the horizontal plane of the bregma. siRNA was injected $24 \mathrm{~h}$ before SBI. According to the manufacturer's instructions, a total volume of $2 \mu \mathrm{l}(500 \mathrm{pmol})$ of accell SMAT pool siRNA pik3cg (Thermo Fisher Scientific) in sterile saline was injected into the ipsilateral ventricle at a rate of $0.5 \mu \mathrm{l} / \mathrm{min}$. Four different sequences targeting pik $3 \mathrm{cg}$ were pooled: 5'-UUGGCAAUUACAAGAGUUU-3', 5' -CUAUUCAG CUCAGUAAAGU-3', 5'-GCAACGUGCACGAUGAUGA-3', and 5'CUGUGAUCCUGGAAGCGUA-3'. This type of PI3K $\gamma$ siRNA pool enters cells without the need for a transfection reagent and is a mixture of four siRNAs, thus providing advantages in both potency and specificity of gene silences. The same volume of scramble siRNA (Accell nontarget-
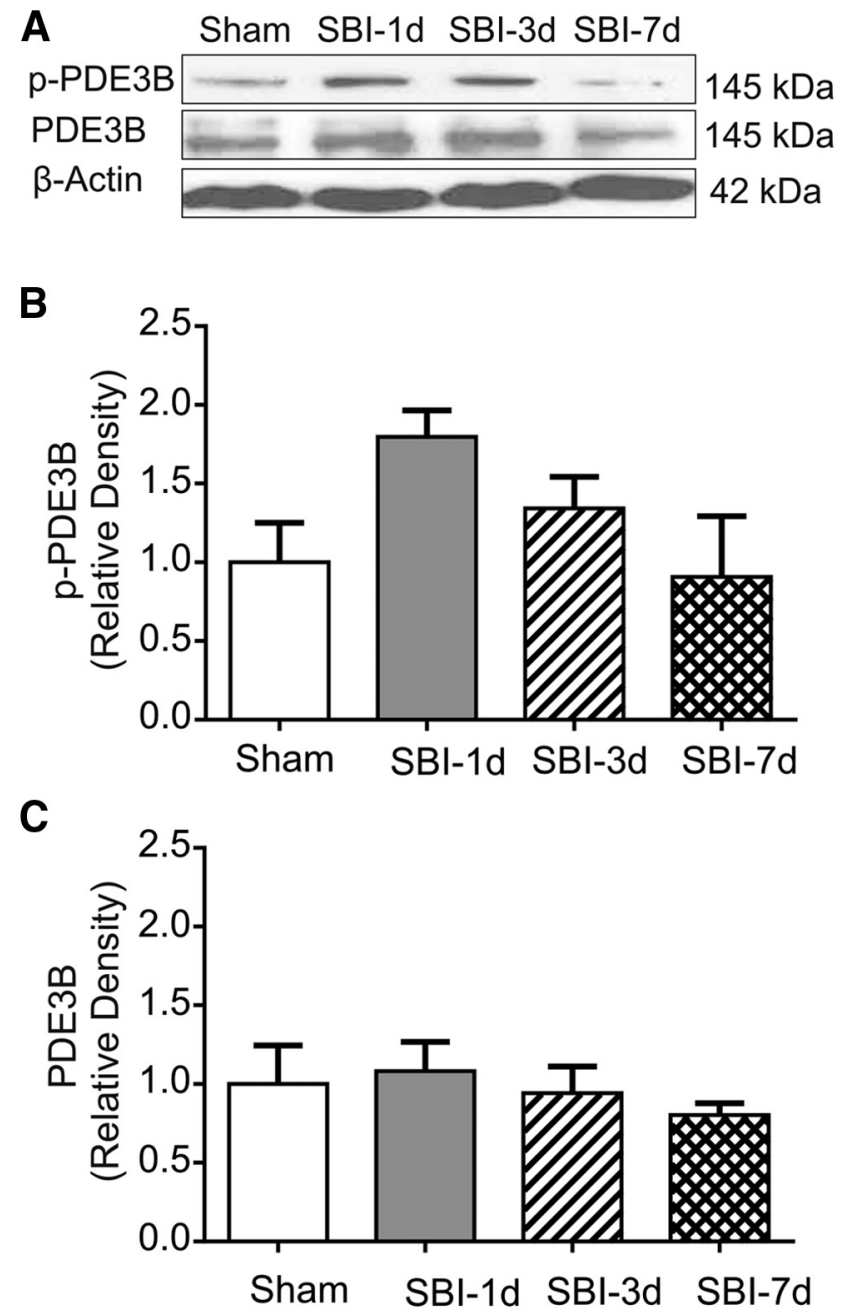

Figure 3. Temporal changes of PDE3B within peri-resection brain tissues after SBI. Western blot showed that there was a tendency toward increase in PDE3B phosphorylation 1 and $3 \mathrm{~d}$ after SBI ( $p=0.197)$, although the total PDE3B levels remained relatively stable compared with shams ( $p=0.38$ ) ( $n=4 /$ group). One-way ANOVA showed that the differences were not statistically significant. $A, B, p=0.197 ; A, C, p=0.38$.

ing pool; Thermo Fisher Scientific) was used as a negative control. A total $2 \mu \mathrm{l}$ of active-recombinant PI3K $\gamma 200 \mathrm{ng}$ or PDE3B $100 \mathrm{ng}$ was injected $30 \mathrm{~min}$ before SBI. To prevent possible leakage, the needle was kept in situ for an additional $10 \mathrm{~min}$ after completing the injection and then withdrawn slowly over $5 \mathrm{~min}$. After removal of the needle, the burr hole was sealed with bone wax, the incision was sutured, and the mice were allowed to recover.

Brain water content. Under deep anesthesia, the rat's brain was quickly removed and dissected into six parts on ice: right frontal, left frontal, right parietal, left parietal, cerebellum, and brainstem. The wet weights of tissue samples were measured immediately and dry weights were obtained after drying in an oven at $105^{\circ} \mathrm{C}$ for $48 \mathrm{~h}$. The percentage of water content in each part was calculated as [(wet weight - dry weight)/wet weight] $\times 100 \%$ (Yamaguchi et al., 2007).

Neurobehavioral tests. Before animals were killed, each had neurological assessments using the modified Garcia and balance beam tests (Yamaguchi et al., 2007). Tests were performed by an examiner (P.S.) kept blinded to treatment information. The modified Garcia test involves a 21-point sensorimotor assessment that includes seven tests. Each test has a score ranging from 0 to 3 , with a maximum score of 21 . The tests evaluate spontaneous activity, side stroking, vibrissae touch, limb symmetry, climbing, lateral turning, and forelimb walking. The balance beam test involves a beam held in place by platforms at either side. Rats 

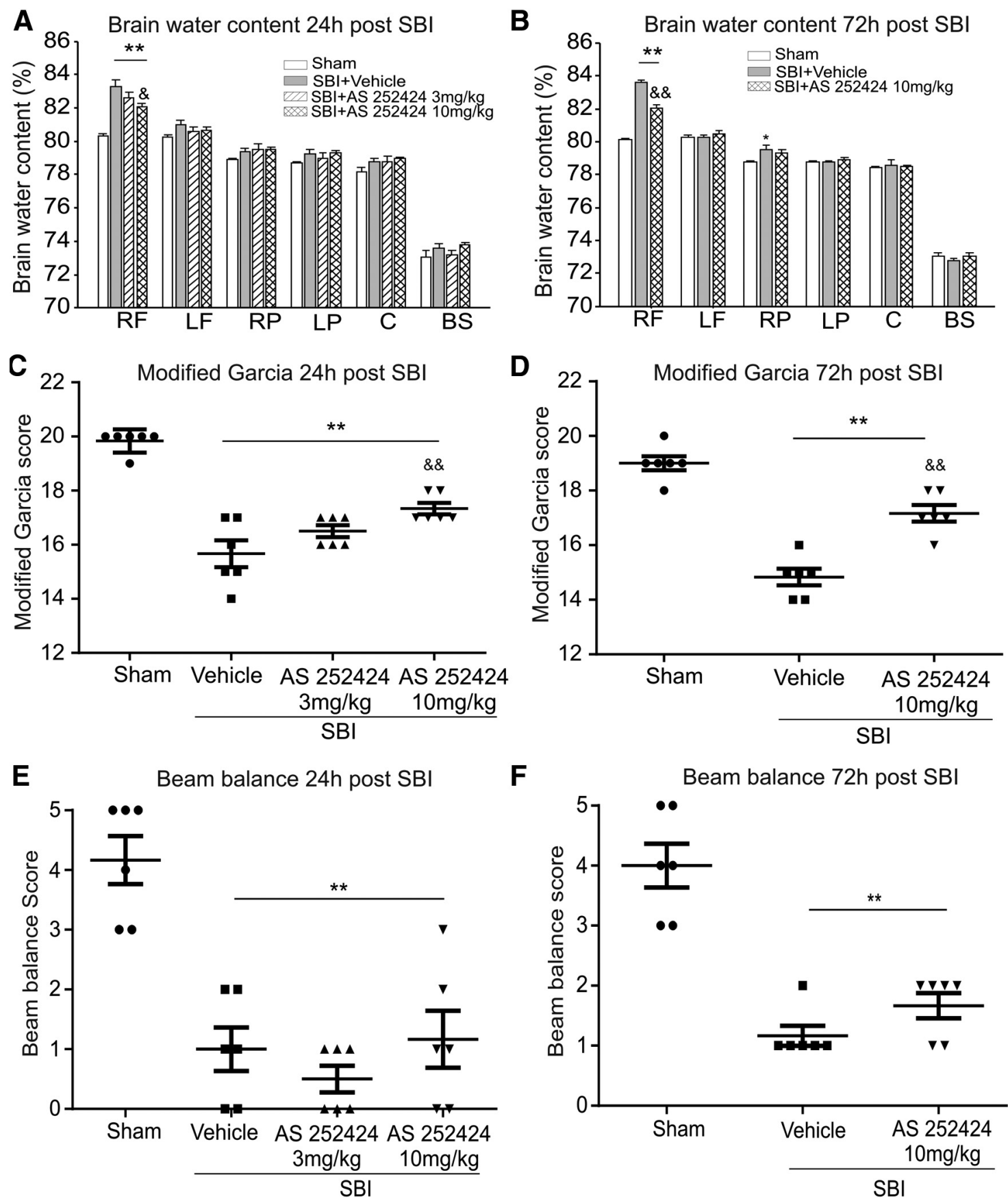

Figure 4. Effect of AS 252424 on brain water content, modified Garcia test, and balance beam test 24 and $72 \mathrm{~h}$ after SBI. Compared with the vehicle-treated SBI animals, AS252424 at dose of 10 $\mathrm{mg} / \mathrm{kg}$ significantly reduced brain water content in peri-resection brain tissues $(\boldsymbol{A}, \boldsymbol{B})$ and improved the modified Garcia neurological function $(\boldsymbol{C}, \boldsymbol{D})$, but not the performance in balance beam test $(\boldsymbol{E}, \boldsymbol{F})\left(n=6\right.$ /group). One-way ANOVA followed by Student-Newman-Keuls post hoc tests were used. $\boldsymbol{A},{ }^{* *} p<0.001$ versus sham; $\& p=0.019$ versus $S B \mathrm{BI}+$ vehicle. $\boldsymbol{B},{ }^{* *} p<0.001$ versus sham; $\& \& p<0.001$ versus $S B I+$ vehicle. $C$, ${ }^{* *} p<0.001$ versus sham; $\& \& p=0.003$ versus $S B I+$ vehicle. $\boldsymbol{D}$, ${ }^{* *} p<0.001$ versus sham; $\& \& p<0.001$ versus $S B I+$ vehicle. $E^{* * *} p<0.001$ versus sham. $F_{,}{ }^{* *} p<0.001$ versus sham. RF, Right frontal lobe; LF, left frontal lobe; RP, right parietal lobe; LP, left parietal lobe; C, cerebellum; BS, brainstem.

were observed for behavior and time to reach either platform. Scores ranged from 0 to 5 , with 5 being the best.

Western blot assay. Western blotting was performed as described previously (Ayer et al., 2012; Chen et al., 2013). At each end time point, rats were perfused with cold PBS, $\mathrm{pH} 7.4$, solution delivered via intracardiac injection, followed by dissection of the brain into right frontal, left frontal, right parietal, left parietal, cerebellum, and brainstem. The brain parts were snap frozen in liquid nitrogen and stored at $-80^{\circ} \mathrm{C}$ until use. Protein extraction from whole-cell lysates were obtained by gently homogenizing them in RIPA lysis buffer (Santa Cruz Biotechnology) with further centrifugation at $14,000 \times \mathrm{g}$ at $4^{\circ} \mathrm{C}$ for $30 \mathrm{~min}$. The supernatant was used as whole-cell protein extract, and the protein concentration was determined using a detergent-compatible assay (Bio-Rad). Equal amounts of protein were loaded on an SDS-PAGE gel. After being electrophoresed and transferred to a nitrocellulose membrane, the membrane was blocked and incubated with the primary antibody overnight at $4^{\circ} \mathrm{C}$. The primary antibodies were rabbit polyclonal anti-PI3K $\gamma(1: 1000)$, rabbit polyclonal anti-PI3K $\alpha$ (1:1000), rabbit polyclonal anti-PI3K $\beta$ (1: $1000)$, rabbit polyclonal anti-PI3K $\delta(1: 1000)$, rabbit polyclonal antiE-selectin (1:1000), goat polyclonal anti-myeloperoxidase (MPO, $1: 4000)$, rabbit polyclonal mast cell tryptase (1:4000), and mouse monoclonal anti-cluster of differentiation 3 (CD3, 1:600) (all from Santa Cruz 
A Brain water content $24 \mathrm{~h}$ post-SBI

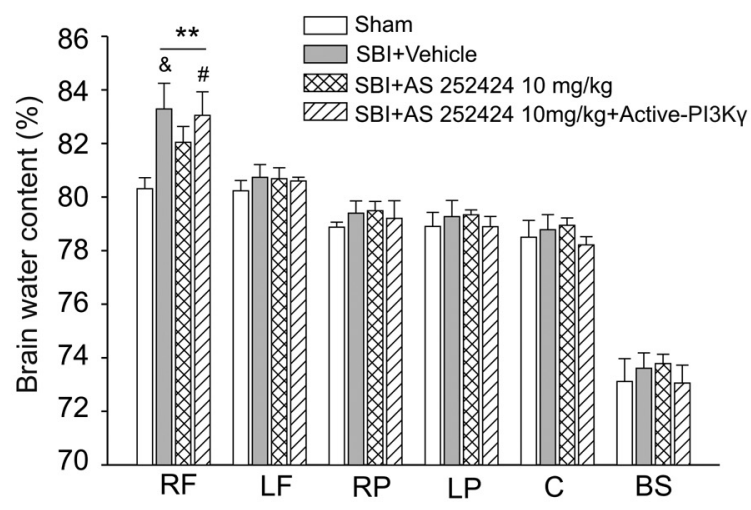

B

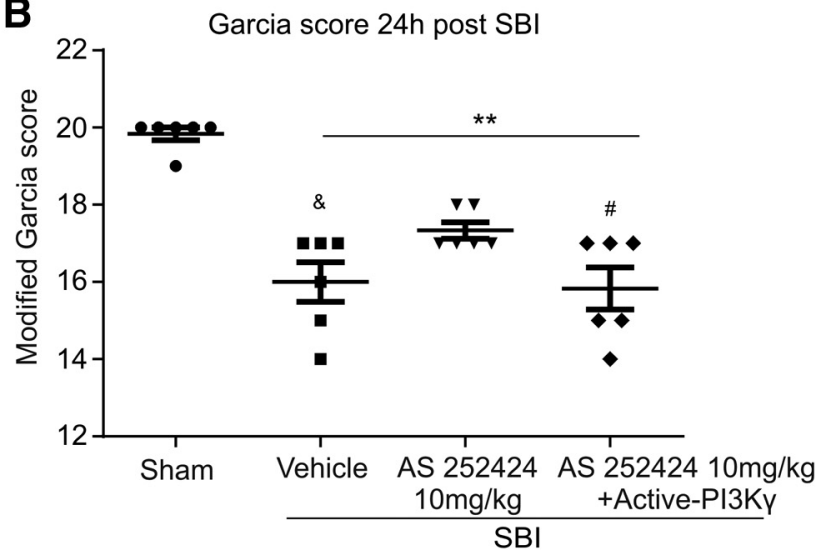

Figure 5. Effect of human recombinant active-PI3K $\gamma$ protein $24 \mathrm{~h}$ after surgery. The protective effects of AS252424 against brain edema $(\boldsymbol{A})$ and neurological deficit $(\boldsymbol{B})$ were significantly reversed by human recombinant active-PI3K $\gamma 24 \mathrm{~h}$ after SBI ( $n=6 /$ group). One-way ANOVA followed by Student-Newman-Keuls post hoc tests were used. $A,{ }^{* *} p<0.001$ versus sham; $\& p=0.024$ versus $S B I+A S 25242410 \mathrm{mg} / \mathrm{kg} ; \# p=0.049$ versus $S B I+A S 25242410 \mathrm{mg} / \mathrm{kg}$. $B_{,}{ }^{* *} p<0.001$ versus sham; $\& p=0.029$ versus $S B I+A S 25242410 \mathrm{mg} / \mathrm{kg} ; \# p=0.04$ versus $\mathrm{SBI}+\mathrm{AS} 25242410 \mathrm{mg} / \mathrm{kg}$. RF, Right frontal lobe; LF, left frontal lobe; RP, right parietal lobe; LP, left parietal lobe; C, cerebellum; $B S$, brainstem.

Biotechnology); monoclonal anti-IL-1 $\beta$ (1:2000; Abcam), goat polyclonal anti-PDE3B (1:500; FabGennix), and rabbit polyclonal antiphosphor-PDE3B (1:500; FabGennix). For loading control, the same membranes were blotted with primary antibody of goat anti- $\beta$-actin (1:8000; Santa Cruz Biotechnology). Nitrocellulose membranes were incubated with appropriate secondary antibodies (1:4000; Santa Cruz Biotechnology) for $1 \mathrm{~h}$ at room temperature. Immunoblot bands were further probed with a chemiluminescence reagent kit (ECL Plus; GE Healthcare). The data were analyzed by ImageJ software.

Immunohistochemistry. Immunohistochemistry was performed as described previously (Chen et al., 2013). Briefly, rats were perfused with ice-cold PBS under deep anesthesia, followed by infusion of $10 \%$ formalin $24 \mathrm{~h}$ after SBI. The brains were harvested and immersed in $10 \%$ formalin at $4^{\circ} \mathrm{C}$ for $24 \mathrm{~h}$, then in $30 \%$ sucrose in PBS until saturation. The brains were cut into $10-\mu \mathrm{m}$-thick coronal sections in a cryostat (CM3050S; Leica Microsystems). The sections were incubated overnight at $4^{\circ} \mathrm{C}$ with the following primary antibodies: rabbit anti-PI3K $\gamma(1: 150)$, costaining with goat anti-MPO (1:100), mouse monoclonal anti-CD3 (1:100), and goat anti-Von Willebrand factor (1:100) (all from Santa Cruz Biotechnology); goat anti-ionized calcium binding adaptor molecule 1 (IBA1, 1:200; Abcam), followed by incubation with appropriate FITC-conjugated secondary antibodies (Jackson ImmunoResearch). Negative control staining was performed by omitting the primary antibody. The sections were visualized with a fluorescence microscope (Olympus BX51).
Statistics. Quantitative data are presented as mean \pm SEM. One-way ANOVA for multiple comparisons and Student-Newman-Keuls post hoc test were used to determine the differences of brain water content, neurological deficits, and Western blot assay among all groups at each time point. $p<0.05$ was considered statistically significant.

\section{Results}

All sham-operated rats survived. The overall mortality of SBI was $15.6 \%$. The mortality was not significantly different among the experimental groups (data not shown).

\section{Changes of endogenous PI3K $\gamma$ level after SBI}

Western blot showed that there were no significant changes in the protein levels of PI3K $\alpha$ and PI3K $\beta$ within peri-resection brain tissues over $7 \mathrm{~d}$ after SBI (Fig. $2 A, B$ ). However, there were significant increases in PI3K $\gamma$ level at 1, 3, and $7 \mathrm{~d}$ after SBI (Fig. 2C). In the absence of significant increases 1 and $3 \mathrm{~d}$ after SBI, PI3K $\delta$ also was elevated $7 \mathrm{~d}$ later (Fig. 2D). Double immunofluorescence staining showed that PI $3 \mathrm{~K} \gamma$ was colocalized with immune cell markers of MPO for neutrophils or CD3 for T-cells at $1 \mathrm{~d}$ after SBI (Fig. 2E).

\section{Changes of endogenous PDE3B level after SBI}

Although total PDE3B levels remained relative stable, there was a tendency toward increased PDE3B phosphorylation ( $\mathrm{p}$-PDE3B) within peri-resection brain tissues $1 \mathrm{~d}$ after SBI ( $p>0.05$; Fig. 3 ).

\section{Effects of AS252424 and human recombinant active-PI3K $\gamma$ protein on brain edema and neurological impairments after SBI}

Twenty-four and $72 \mathrm{~h}$ after surgery, SBI animals had higher brain water content within peri-resection tissues and neurological deficits compared with the shams (Fig. 4). Compared with animals treated with vehicle, PI3K $\gamma$ inhibitor AS252424 at a dose of 10 $\mathrm{mg} / \mathrm{kg}$ reduced brain edema and improved neurological performance (the Garcia test), but not the balance beam 24 and $72 \mathrm{~h}$ after SBI (Fig. 4).

Human recombinant active-PI3K $\gamma$ protein, administered intracerebroventricularly $30 \mathrm{~min}$ before surgery, countered the beneficial effect of the PI3K $\gamma$ inhibitor AS252424 on brain water content and neurological outcome at $24 \mathrm{~h}$ after SBI (Fig. 5).

\section{Effects of AS252424 and human recombinant active-PI3K $\gamma$} protein on neuroinflammation $24 \mathrm{~h}$ after SBI

Western blot assay showed significantly higher protein levels of MPO, CD3, mast cell tryptase, E-selectin, and IL-1 $\beta$ in periresection brain tissues after SBI (Fig. 6). Selective inhibition of PI3K $\gamma$ by AS252424 $(10 \mathrm{mg} / \mathrm{kg})$ reduced the expression of those inflammatory markers (Fig. 6). Human recombinant activePI3K $\gamma$ protein partially abolished the anti-inflammation effect of AS252424 (Fig. 6).

\section{Role of downstream enzyme PDE3B in PI3K $\gamma$-mediated injury $24 \mathrm{~h}$ after SBI}

Compared with vehicle-treated SBI, PI3K $\gamma$ inhibitor AS252424 (10 $\mathrm{mg} / \mathrm{kg}$ ) administration had no significant effect on PDE3B phosphorylation, even though a tendency to decrease was shown $24 \mathrm{~h}$ after SBI (Fig. 7A). Without significantly increasing p-PDE3B level in peri-resection brain tissues (Fig. 7A), exogenous human recombinant active-PDE3B protein reversed the effects of AS252424 in the Garcia score at $24 \mathrm{~h}$ after SBI (Fig. 7B). 


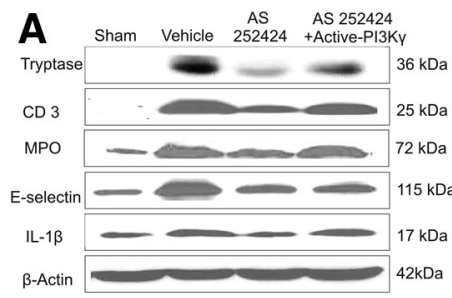

D

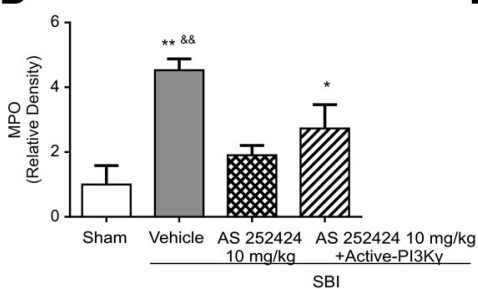

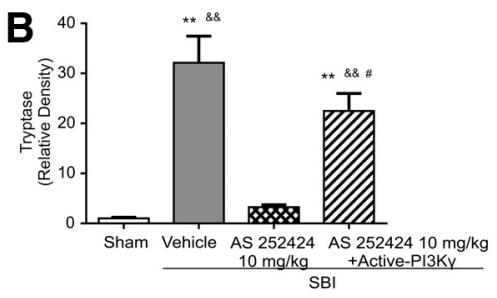

$\mathbf{E}$

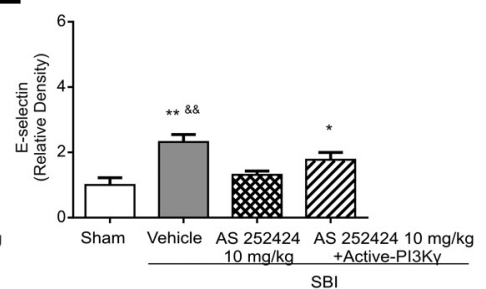

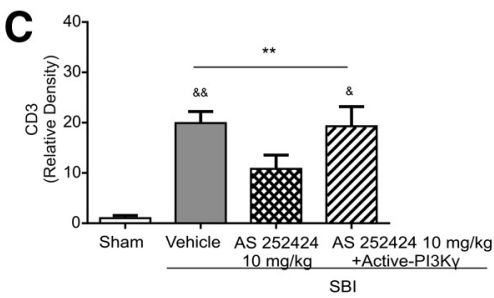

$\mathbf{F}$

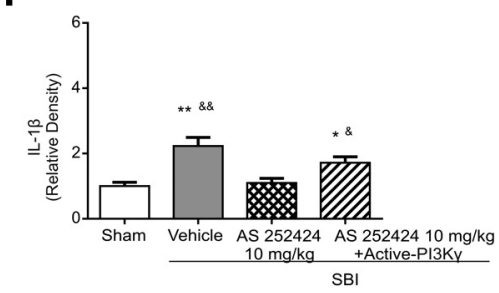

Figure 6. Effect of AS252424 and human recombinant active-PI3K $\gamma$ protein on neuroinflammation associated with SBI $24 \mathrm{~h}$ after surgery. Representative images are shown of Western blot assay for mast cell tryptase, CD3, MPO, E-selectin, and IL-1 $\beta$ level within peri-resection brain tissues ( $A$ ). Compared with the vehicle-treated SBI, AS252424 significantly reduced levels of mast cell tryptase $(\boldsymbol{B})$, T-cell associated with CD 3 level $(\boldsymbol{C})$, neutrophils associated MPO level $(\boldsymbol{D})$, cell-adhesion molecule E-selectin $(\boldsymbol{E})$, and IL-1 $\beta$ cytokine $(\boldsymbol{F})$ elevation by SBI. Human recombinant active-PI3K $\gamma$ partially reversed the protective effect of AS252424 against neuroinflammation ( $n=6 /$ group). One-way ANOVA followed by Student-Newman-Keuls post hoc tests were used. $\boldsymbol{B}$, ${ }^{* *} p<0.001$ versus sham; $\& \& p<0.001$ versus $S B I+A S 25242410 \mathrm{mg} / \mathrm{kg} ; \# p=0.016$ versus $S B I+$ vehicle. $C$, ${ }^{* *} p<0.001$ versus sham; $\& \& p=0.003$ versus $S B I+A S 25242410 \mathrm{mg} / \mathrm{kg} ; \& p=0.019$ versus $S B I+A S 25242410 \mathrm{mg} / \mathrm{kg} . D,{ }^{*} p=0.023$ versus sham; ${ }^{* *} p<0.001$ versus sham; $\& \& p=0.004$ versus $S B I+A S 25242410 \mathrm{mg} / \mathrm{kg} . E,{ }^{*} p=0.039$ versus sham; ${ }^{* *} p=0.002$ versus sham; $\& \& p=$ 0.008 versus $S B I+A S 25242410 \mathrm{mg} / \mathrm{kg} . F_{,}{ }^{*} p=0.029$ versus sham; ${ }^{* *} p<0.001$ versus sham; $\& p=0.026$ versus SBI $+A S 25242410 \mathrm{mg} / \mathrm{kg} ; \& \& p=0.001$ versus SBI $+\mathrm{AS} 25242410 \mathrm{mg} / \mathrm{kg}$.

A

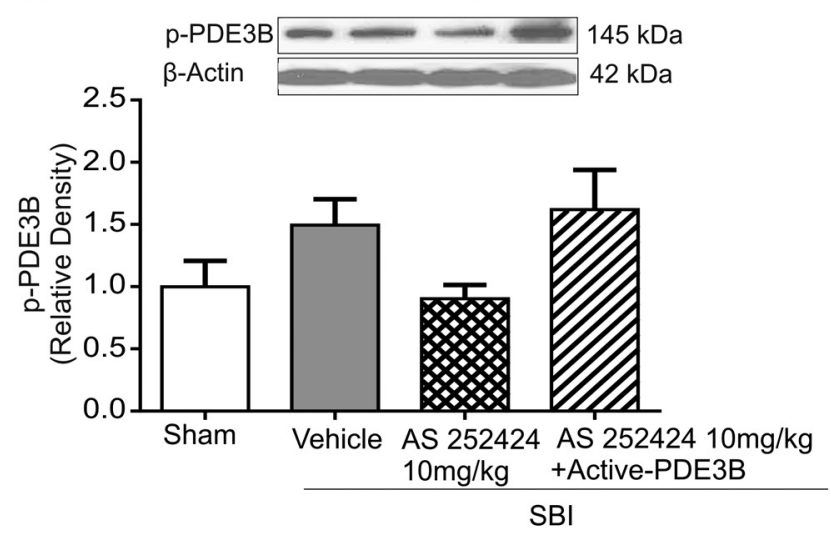

B

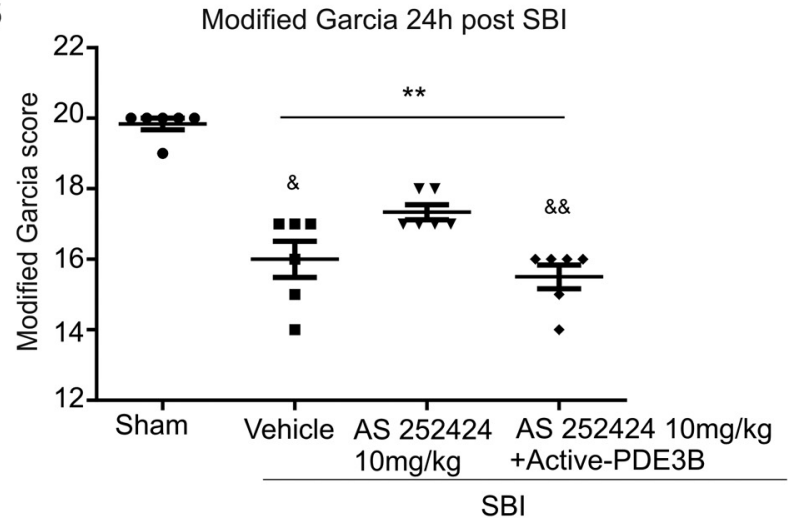

Figure 7. Effect of exogenous human recombinant active-PDE3B at $24 \mathrm{~h}$ after surgery. $A$, Western blot showed a trend toward reduction in PED3B phosphorylation by AS252424, which tended to be reversed by active-PDE3B administration. However, these differences did not reach statistical significance $(p=0.085)$. $B$, The protective effects of AS252424 on neurological deficit were significantly reversed by active PDE3B ( $n=6$ /group). One-way ANOVA followed by Student-Newman-Keuls post hoc tests were used. ${ }^{* *} p<0.001$ versus sham; $\& p=0.011$ versus SBI + AS252424 $10 \mathrm{mg} / \mathrm{kg} ; \& \& p=0.003$ versus $S B I+A S 25242410 \mathrm{mg} / \mathrm{kg}$.

\section{Effects of AS605240 on brain edema and neurological} impairments after SBI

SBI animals treated by the selective PI3K $\gamma$ inhibitor AS605240 at a dose of $10 \mathrm{mg} / \mathrm{kg}$ demonstrated similar results of significant reduction in brain water content in peri-resection brain tissues and improvement in the Garcia neurological performance at $24 \mathrm{~h}$ after SBI compared with vehicle-treated SBI (Fig. 8).

\section{Effects of PI3K $\gamma$ siRNA on PI3K $\gamma$ levels and outcomes $24 \mathrm{~h}$ after SBI}

Twenty-four hours after SBI, Western blot showed that the $\mathrm{PI} 3 \mathrm{~K} \gamma$ protein levels had increased in peri-resection brain tissue (Fig. 9A). Compared with the vehicle-treated and scramble siRNA-treated SBI, PI3K $\gamma$ siRNA reduced PI3K $\gamma$ levels (Fig. 9A). In addition, PI3K $\gamma$ siRNA treatment attenuated brain edema in peri-resection brain tissues (Fig. 9B) and improved neurological function (Fig. 9C,D). Double immunofluorescence staining showed PI3K $\gamma$ expression in brain endothelia and microglia cells in shamoperated and SBI animals at $24 \mathrm{~h}$ after injury, which were suppressed by PI3K $\gamma$ siRNA intracerebroventricular injection (Fig. 10).

\section{Discussion}

In the present study, we have made the following observations: (1) endogenous PI3K $\gamma$ levels were significantly elevated in periresection brain tissues at $1 \mathrm{~d}$ and up to $7 \mathrm{~d}$ after corticotomy in a rat SBI model; (2) there was a tendency toward increase of endogenous PDE3B phosphorlation, a downstream enzyme of $\mathrm{PI} 3 \mathrm{~K} \gamma$ proinflammation signaling pathways, in the peri-resection brain tissues at $1 \mathrm{~d}$ after SBI; (3) the selective PI3K $\gamma$ inhibitor AS252424 at a dose of $10 \mathrm{mg} / \mathrm{kg}$ significantly attenuated SBIinduced brain edema and neurological deficits 24 and $72 \mathrm{~h}$ after SBI; (4) the improved outcomes by the PI3K $\gamma$ inhibitor AS252424 were associated with less immune cell infiltration, activation, and cytokine release in peri-resection brain tissues $24 \mathrm{~h}$ after SBI; (5) exogenous human recombinant active-PI3K $\gamma$ protein partially offset the neuroprotection provided by the selective PI3K $\gamma$ inhibitor AS252424 $24 \mathrm{~h}$ after SBI; (6) exogenous human recombinant active-PDE3B reversed the benefits of AS252424 on 

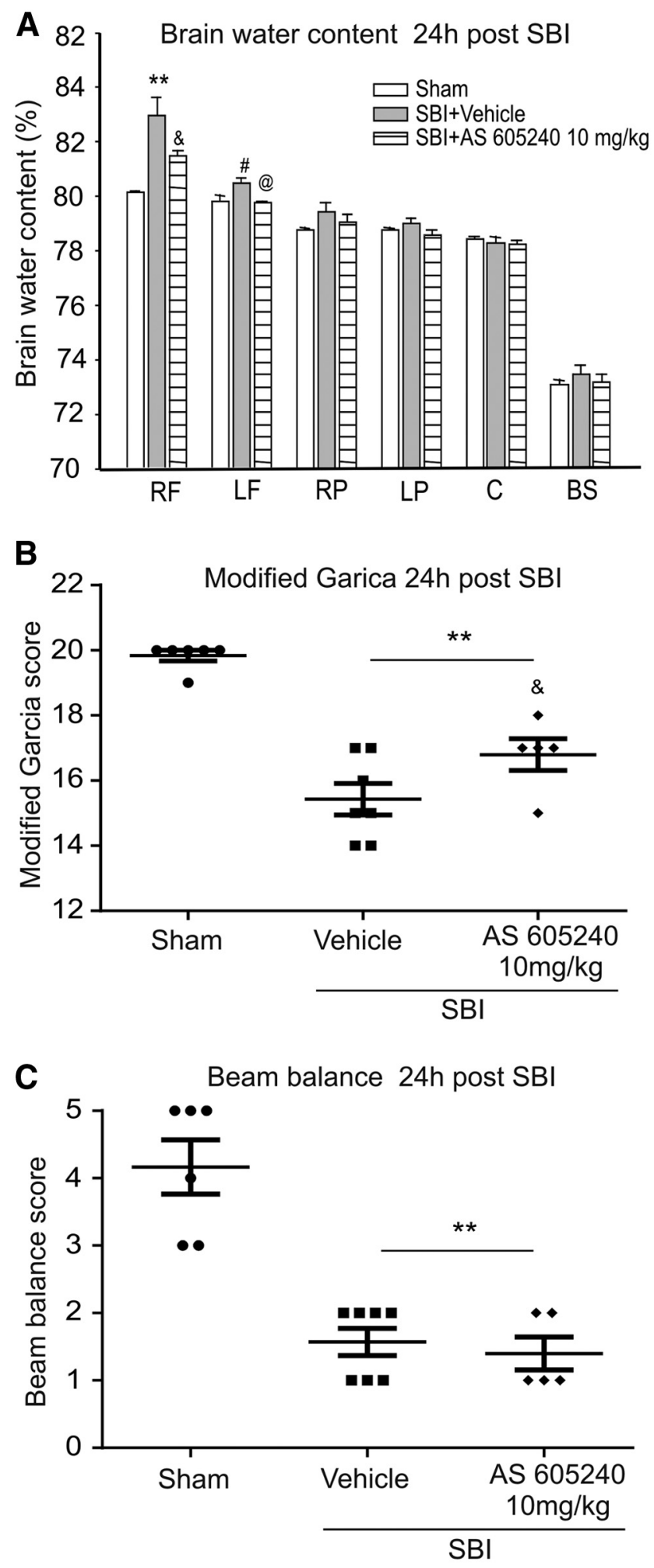

Figure 8. Effect of AS605240 on brain water edema, the modified Garcia test, and balance beam test $24 \mathrm{~h}$ after SBI. Compared with the vehicle-treated SBI animals, AS605240 significantly reduced brain water content in peri-resection brain tissues $(\boldsymbol{A})$ and improved the modified Garcia neurological function $(\boldsymbol{B})$, but not the performance in balance beam test $(\boldsymbol{C})(n=6$ in sham, $n=7$ in SBI + vehicle, $n=5$ in SBI + AS605240). One-way ANOVA followed by Student-Newman-Keuls post hoc tests were used. $A,{ }^{* *} p=0.001$ versus sham; $\# p=0.022$ versus sham; $\& p=0.038$ versus $S B I+$ vehicle. ${ }^{\circledR} p=0.044$ versus $S B I+$ vehicle. $B,{ }^{* *} p<$ 0.001 versus sham; $\& p=0.035$ versus $S B I+$ vehicle. $D,{ }^{* *} p<0.001$ versus sham. RF, Right frontal lobe; $L F$, left frontal lobe; $R P$, right parietal lobe; $L P$, left parietal lobe; $C$, cerebellum; $B S$, brainstem. neurological outcomes at $24 \mathrm{~h}$ after SBI; (7) another selective PI3K $\gamma$ inhibitor, AS605240, at a dose of $10 \mathrm{mg} / \mathrm{kg}$ produced a similar protective effect against brain edema and neurological deficit $24 \mathrm{~h}$ after SBI; and (8) PI3K $\gamma$ siRNA decreased the PI3K $\gamma$ level, reduced brain edema, and improved neurological outcomes $24 \mathrm{~h}$ after SBI. These results demonstrate that PI3K $\gamma$ and its downstream enzyme, PDE3B, are involved in neuroinflammation in adjacent resection brain tissues after SBI.

PI3K $\gamma$ upregulation within $24 \mathrm{~h}$ was reported previously in a mouse model of focal cerebral ischemia (Jin et al., 2010b). Genetic ablation of the PI3K $\gamma$ gene resulted in less ischemiainduced microglia activation and blood-brain barrier (BBB) disruption in mice (Jin et al., 2010b; Jin et al., 2011). In the present study, there were significant increases in the PI $3 \mathrm{~K} \gamma$ protein level at $1 \mathrm{~d}$ and up to $7 \mathrm{~d}$ after SBI. PI3K $\gamma$ was localized in immune cells such as neutrophils and T cells. The pattern of PI3K $\gamma$ elevation conforms to the time course of inflammatory cells recruitment after brain injury (Ling et al., 2003; Jin et al., 2010a; Rhodes, 2011), suggesting PI3K $\gamma$ involvement in neuroinflammation after SBI. In addition to PI3K $\gamma$ in class IB of PI3K, there are three members in subclass IA of PI3K, PI3K $\alpha, \operatorname{PI} 3 \mathrm{~K} \beta$, and $\mathrm{PI} 3 \mathrm{~K} \delta$, which are activated by receptor tyrosine kinases (Barberis and Hirsch, 2008). Ubiquitously expressed PI $3 \mathrm{~K} \alpha$ and PI3K $\beta$ are vital for cell growth, division, and survival (Venable et al., 2010) and genetic ablations of each resulted in early embryonic lethality ( $\mathrm{Bi}$ et al., 1999; Bi et al., 2002). PI3K $\delta$, also mainly expressed in hematopoietic cells, cooperates with PI3K $\gamma$ in immune-mediated inflammation with a complex epistatic interaction with activities critical during the process of inflammatory diseases (Liu et al., 2007; Rommel et al., 2007; Cushing et al., 2012). In the absence of changes in PI3K $\alpha$ and PI $3 \mathrm{~K} \beta, \mathrm{PI} 3 \mathrm{~K} \delta$ was the only PI3K class IA isoform significantly increased within peri-resection brain tissues $7 \mathrm{~d}$ after corticotomy. Future studies are needed to investigate the specific role of PI3K $\delta$ in neuroinflammation after SBI.

Accumulation of leukocytes into the injured brain area is crucial to the extent of inflammation and secondary brain damage (Jin et al., 2010a; Ma et al., 2011; Rhodes, 2011). We found there were higher levels of MPO, CD3, and mast cell tryptase in the peri-resection tissues of SBI animals than shams, suggesting that the increased neutrophil, T-cell infiltration, and mast cell degranulation occurred after SBI. It was accompanied by increases in proinflammatory cytokine levels of IL- $1 \beta$. Given the central role of PI3K $\gamma$ in regulating chemotaxis of leukocytes, as well as immune cell activation (Rückle et al., 2006), inhibition of the common signaling pathway of $\mathrm{PI} 3 \mathrm{~K} \gamma$ is expected to provide comprehensive anti-inflammation effects and thus benefit overall outcome after SBI. The fact that its expression is restricted mainly to the hematopoietic system, although not exclusively, ensures overall benefits in the absence of severe side effects (Hirsch et al., 2000). PI3K $\gamma$ knock-out mice had significantly less infarct volumes and better neurological scores $24 \mathrm{~h}$ after focal ischemic stroke (Jin et al., 2011). PI3K $\gamma$ inhibition prevented $\beta$-amyloid1-40 peptide-induced cognitive deficits and synaptic dysfunction in mice (Passos et al., 2010). In agreement with these observations, we found that PI $3 \mathrm{~K} \gamma$ inhibitor reduced neuroinflammation, leading to better outcomes at 24 and $72 \mathrm{~h}$ after SBI. Due to our model limitations that brain edema and neurological deficits gradually recede over $14 \mathrm{~d}$, we did not evaluate the longterm effects of PI3K $\gamma$ inhibitor. However, preclinical studies have demonstrated that daily administration of PI $3 \mathrm{~K} \gamma$ inhibitors benefit systemic inflammatory diseases for up to 1 month without evident side effects (Barber et al., 2005; Camps et al., 2005; Martin et al., 2010). Our findings complement earlier reports demon- 
A

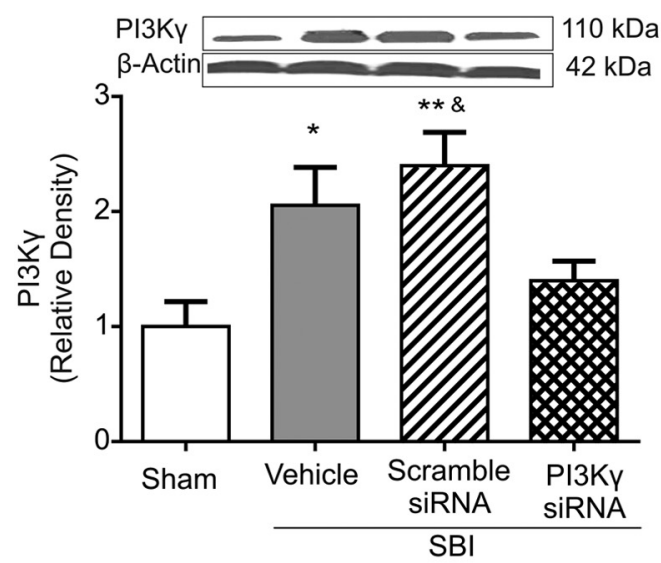

C

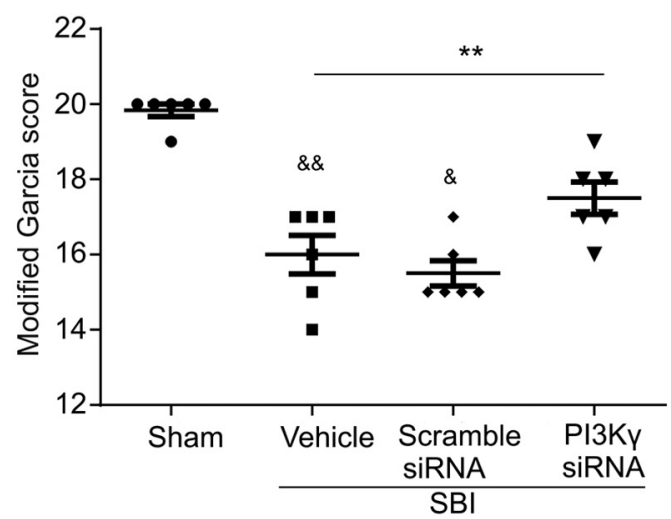

B Brain water content $24 \mathrm{~h}$ post-SBI

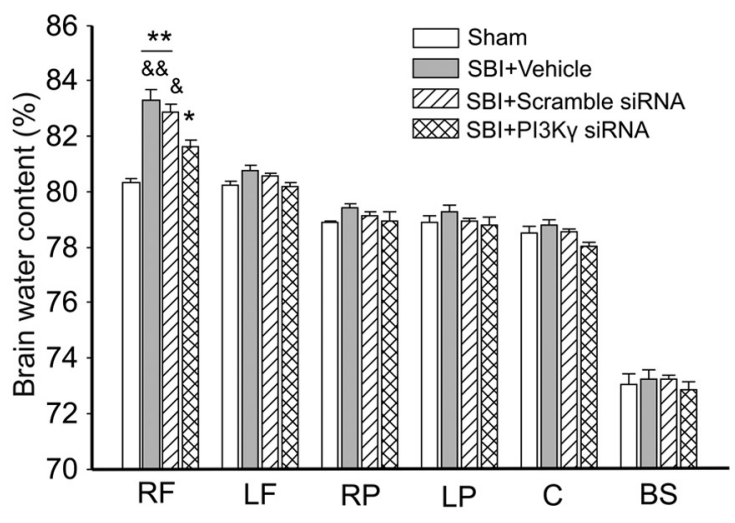

D Beam Balance 24h post SBI

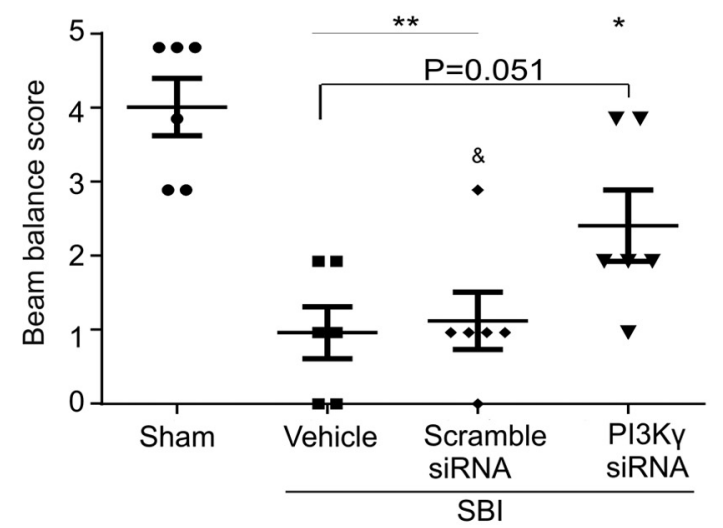

Figure 9. Effect of PI3K $\gamma$ siRNA on brain water content and neurological score $24 \mathrm{~h}$ after SBI. Compared with vehicle- or scramble siRNA-treated SBI animals, PI3K $\gamma$ siRNA significantly reduced PI3K $\gamma$ levels in peri-resection brain tissue $(\boldsymbol{A})$. PI3K siRNA-treated SBl animals were associated with significantly less brain water content $(\boldsymbol{B})$ and a better neurological function $(\boldsymbol{C}, \boldsymbol{D})(n=6 / \mathrm{group})$. One-way ANOVA followed by Student-Newman-Keuls posthoctests were used. $\boldsymbol{A},{ }^{*} p=0.028$ versus sham; ${ }^{* *} p=0.005$ versus sham; $\& p=0.043$ versus SBI $+\mathrm{PI} 3 \mathrm{~K} \gamma$ siRNA. $\boldsymbol{B}$, ${ }^{*} p=0.003$ versus sham; ${ }^{* *} p<0.001$ versus sham; $\& p=0.005$ versus SBI + PI3K $\gamma$ siRNA; $\& \& p=0.001$ versus $S B I+P I 3 K \gamma$ siRNA. $C,{ }^{* *} p<0.001$ versus sham; $\& p=0.003$ versus $S B I+P I 3 K \gamma$ siRNA; $\& \& p<$ 0.001 versus $S B I+$ PI $3 K \gamma$ siRNA. $D,{ }^{*} p=0.001$ versus sham; ${ }^{* *} p<0.001$ versus sham; $\& p=0.036$ versus SBI + PI3K $\gamma$ siRNA. RF, Right frontal lobe; LF, left frontal lobe; $R P$, right parietal lobe; $L P$, left parietal lobe; C, cerebellum; $B S$, brainstem.

strating impaired leukocyte trafficking to inflamed venues of rodents in which PI3K $\gamma$ activation was blocked using a pharmacological or genetic approach (Barber et al., 2005; Camps et al., 2005; Ferrandi et al., 2007). The absence of PI3K $\gamma$ activity impaired lipid product accumulation at the leading edge and actin rearrangement in leukocytes (Rickert et al., 2000) and stable adhesion to the endothelial wall (Smith et al., 2006), thus hampering their migration and infiltration. Conversely, endothelial PI3K $\gamma$ blockade reduced E-selectin-mediated attachment and increased neutrophil rolling velocity (Puri et al., 2005; Ghigo et al., 2010). PI3K $\gamma$ expresses in rodent brain endothelial cells and microglia (Jin et al., 2010a,b). PI3K $\gamma$ deficiency mice have a lower E-selectin level after focal brain ischemia (Jin et al., 2011). Consistent with this, in our study, PI3K $\gamma$ inhibitor diminished E-selectin elevation after SBI. Drug delivered through the CSF compartment could penetrate into the brain parenchyma and circulate into blood along CSF flow tracks (Kuo and Smith, 2014). Therefore, intracerebroventricular PI3K $\gamma$ siRNA administration suppressed PI3K $\gamma$ expression in brain endothelial cells and microglia, which could further reduce endothelial E-selectin-mediated leukocyte adhesion. To some extent, PI3K $\gamma$ siRNA may also suppress leukocyte PI3K $\gamma$ expression and associated chemotaxis.
Brain mast cells located mainly in meninges and several perivascular brain structures responded and degranulated to a multitude of physical/chemical challenges (Dimitriadou et al., 1990; Zhuang et al., 1996). By releasing potent preformed vasoactive and inflammatory mediators, including proteases and cytokines, that then act on cerebral vessels, mast cells initiate and promote breakdown of $\mathrm{BBB}$ and secondary inflammatory responses after focal brain ischemia (Strbian et al., 2007; Stokely and Orr, 2008; Jin et al., 2009). After SBI, increased tryptase in the brain region surrounding resection implicated the participation of mast cell activation and degranulation in initiating and promoting pathological processes associated with SBI. AS252424 significantly reduced tryptase release after SBI. Our findings echo previous studies in experimental systemic anaphylaxis showing that $\mathrm{PI} 3 \mathrm{~K} \gamma$ inhibition reduced mast cell degranulation and that PI3K $\gamma$ deficiency animals were resistant to passive systemic anaphylaxis (Laffargue et al., 2002). PI3K $\gamma$ inhibitor or PI3K $\gamma$ knock-out could interrupt the degranulation amplification in mast cells (Laffargue et al., 2002).

Notably, neurobehavioral benefits were not evident in the balance beam test. Given that the balance beam test examines the overall performance of a task, rats can compensate for deficits using the uninjured body side, thus reducing the sensitivity to reveal unilateral 
A

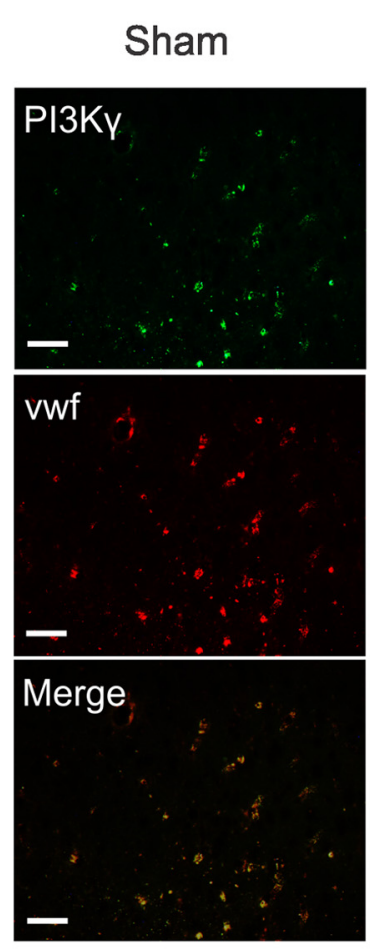

B
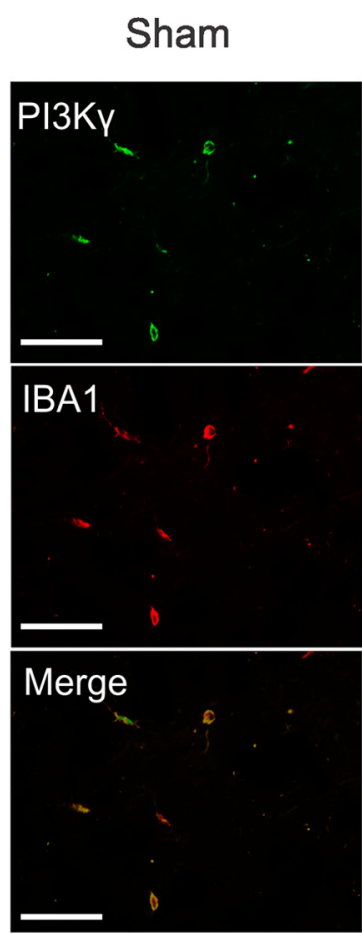

Scrmable siRNA $+\mathrm{SBI}$

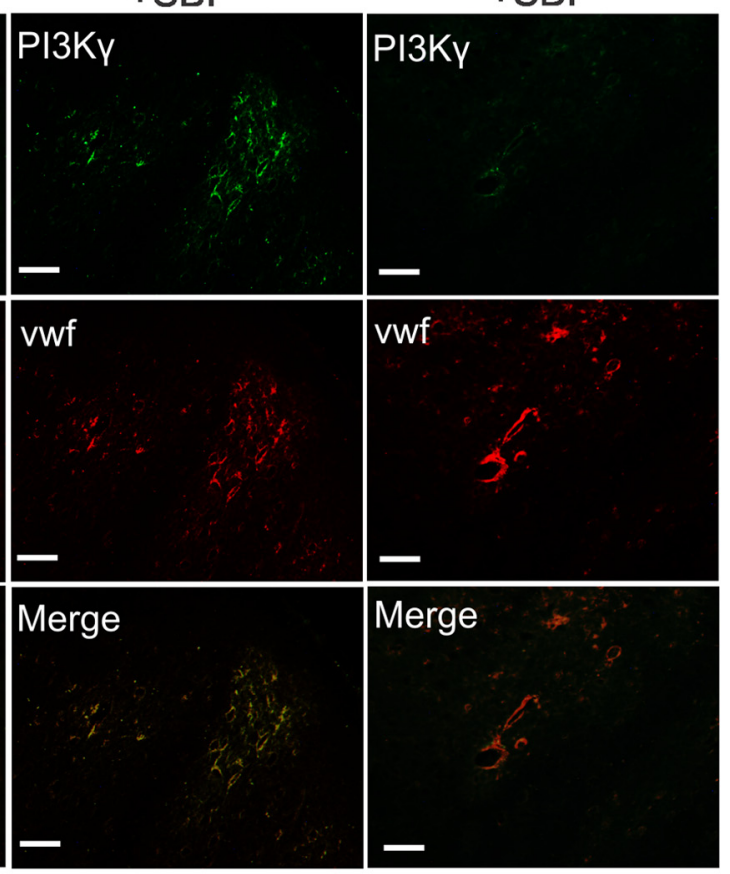

Scrmable siRNA $+\mathrm{SBI}$
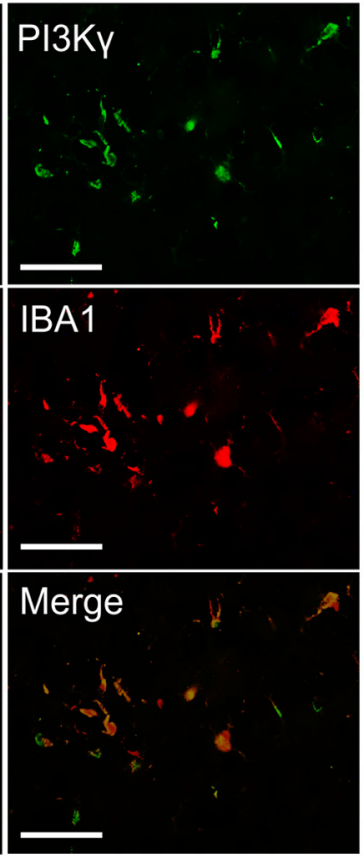

PI3KY SiRNA $+\mathrm{SBI}$

\section{PI3KY siRNA} $+\mathrm{SBI}$
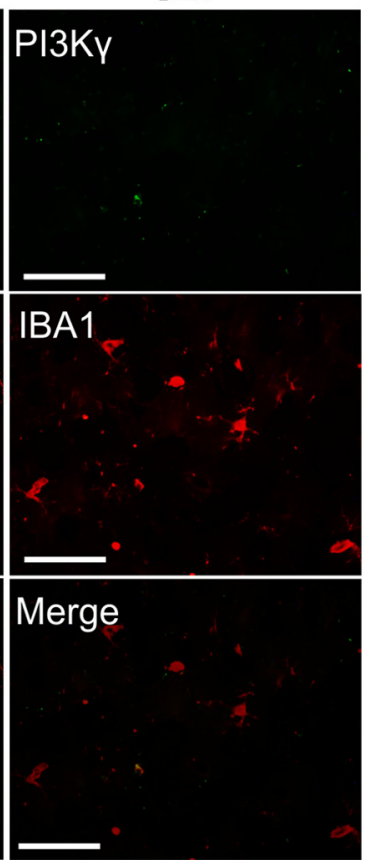

Figure 10. Effects of PI3K $\gamma$ siRNA on brain resident cells. Representative immunohistochemistry microphotographs of PI3K $\gamma$ staining with endothelia cells (Von Willebrand factor; $\boldsymbol{A}$ ) and microglia (IBA1; $\boldsymbol{B}) 24 \mathrm{~h}$ hours after SBI. Sham- and scramble siRNA-pretreated SBI rats expressed PI3K $\gamma$ in brain endothelia and microglia within the ipsilateral frontal lobe. PI3K $\gamma$ siRNA intracerebroventricular injection suppressed endothelia and microglia PI3K $\gamma$ expression after SBI. Scale bar, $50 \mu \mathrm{m}$.

brain damage. In the mouse model of intracerebral hemorrhage, the balance beam test showed a limited ability to identify the sensorimotor deficits compared with the modified Garcia neuroscore (Krafft et al., 2014). Nevertheless, either pharmacological PI3K $\gamma$ inhibition or siRNA-mediated PI3K $\gamma$ reduction significantly improved compos- ite neurological function evaluated by the modified Garcia test after SBI.

When exogenous human recombinant active-PI3K $\gamma$ was administrated, it reversed the protective effect of selective PI3K $\gamma$ inhibitor against neuroinflammation, brain edema, and neurological deficit in SBI, confirming the detrimental role of PI3K $\gamma$ in SBI pathological progression.

Stimulatory effects of PI3K $\gamma$ on PDE3B activity have been documented in several types of cells through kinaseindependent protein-protein direct interaction and downstream protein kinase B/Akt-dependent phosphorylation of PDE3B (Patrucco et al., 2004; Baragli et al., 2011; Degerman et al., 2011; Perino et al., 2011; Schmidt et al., 2013). ActivePDE3B degrades the phosphodiester bond in CAMP, which could further activate a variety of immune cell functions (Serezani et al., 2008; Schmidt et al., 2013). Selective PI3K $\gamma$ inhibitor was able to suppress microglial phagocytosis, possibly through preventing Akt-dependent PDE3B phosphorylation (Schmidt et al., 2013). Along with PI3K $\gamma$ elevation in the present study, there was a tendency toward increase in PDE3B phosphorylation within peri-resection brain tissues at $24 \mathrm{~h}$ after SBI. SBI animals treated with the selective PI3K $\gamma$ inhibitor AS252424 had lower levels of phosphorylated PDE3B. The administration of human recombinant active PDE3B reversed the protective effect of AS252424 against SBI-induced neurological deficit. These results suggested that the proinflammation effects of $\mathrm{PI} 3 \mathrm{~K} \gamma$ may be at least in part through PDE3B activation.

In conclusion, signaling through $\mathrm{PI} 3 \mathrm{~K} \gamma$ appears to be a common platform controlling diverse immune modulation after SBI. Our study underscores the suppression of multimodal inflammatory cells achieved by selective PI3K $\gamma$ inhibition in the setting of SBI. Local administration of human recombinant active-PI3K $\gamma$ and active-PDE3B proteins partially reversed the neuroprotective effects associated with pharmacological inhibition of $\mathrm{PI} 3 \mathrm{~K} \gamma$. Selective $\mathrm{PI} 3 \mathrm{~K} \gamma$ inhibitor may offer pleiotropic antiinflammation effects in patients undergoing neurosurgery and may thus prove beneficial to postoperative outcomes.

\section{References}

Ayer RE, Jafarian N, Chen W, Applegate RL 2nd, Colohan AR, Zhang JH (2012) Preoperative mucosal tolerance to brain antigens and a neuroprotective immune response following surgical brain injury. J Neurosurg 116:246-253. CrossRef Medline

Baragli A, Ghè C, Arnoletti E, Granata R, Ghigo E, Muccioli G (2011) Acylated and unacylated ghrelin attenuate isoproterenol-induced lipolysis in 
isolated rat visceral adipocytes through activation of phosphoinositide 3-kinase gamma and phosphodiesterase 3B. Biochim Biophys Acta 1811: 386-396. CrossRef Medline

Barber DF, Bartolomé A, Hernandez C, Flores JM, Redondo C, FernandezArias C, Camps M, Rückle T, Schwarz MK, Rodríguez S, Martinez-A C, Balomenos D, Rommel C, Carrera AC (2005) PI3Kgamma inhibition blocks glomerulonephritis and extends lifespan in a mouse model of systemic lupus. Nat Med 11:933-935. Medline

Barberis L, Hirsch E (2008) Targeting phosphoinositide 3-kinase gamma to fight inflammation and more. Thromb Haemost 99:279-285. Medline

Bi L, Okabe I, Bernard DJ, Wynshaw-Boris A, Nussbaum RL (1999) Proliferative defect and embryonic lethality in mice homozygous for a deletion in the p110alpha subunit of phosphoinositide 3-kinase. J Biol Chem 274: 10963-10968. CrossRef Medline

Bi L, Okabe I, Bernard DJ, Nussbaum RL (2002) Early embryonic lethality in mice deficient in the p110beta catalytic subunit of PI 3-kinase. Mamm Genome 13:169-172. Medline

Camps M, Rückle T, Ji H, Ardissone V, Rintelen F, Shaw J, Ferrandi C, Chabert C, Gillieron C, Françon B, Martin T, Gretener D, Perrin D, Leroy D, Vitte PA, Hirsch E, Wymann MP, Cirillo R, Schwarz MK, Rommel C (2005) Blockade of PI3Kgamma suppresses joint inflammation and damage in mouse models of rheumatoid arthritis. Nat Med 11:936-943. Medline

Chen S, Ma Q, Krafft PR, Hu Q, Rolland W 2nd, Sherchan P, Zhang J, Tang J, Zhang JH (2013) P2X7R/cryopyrin inflammasome axis inhibition reduces neuroinflammation after SAH. Neurobiol Dis 58:296-307. CrossRef Medline

Cushing TD, Metz DP, Whittington DA, McGee LR (2012) PI3Kdelta and PI3Kgamma as targets for autoimmune and inflammatory diseases. J Med Chem 55:8559-8581. CrossRef Medline

Degerman E, Ahmad F, Chung YW, Guirguis E, Omar B, Stenson L, Manganiello V (2011) From PDE3B to the regulation of energy homeostasis. Curr Opin Pharmacol 11:676-682. CrossRef Medline

Dimitriadou V, Lambracht-Hall M, Reichler J, Theoharides TC (1990) Histochemical and ultrastructural characteristics of rat brain perivascular mast cells stimulated with compound $48 / 80$ and carbachol. Neuroscience 39:209-224. CrossRef Medline

Ferrandi C, Ardissone V, Ferro P, Rückle T, Zaratin P, Ammannati E, Hauben E, Rommel C, Cirillo R (2007) Phosphoinositide 3-kinase gamma inhibition plays a crucial role in early steps of inflammation by blocking neutrophil recruitment. J Pharmacol Exp Ther 322:923-930. CrossRef Medline

Ghigo A, Damilano F, Braccini L, Hirsch E (2010) PI3K inhibition in inflammation: Toward tailored therapies for specific diseases. BioEssays 32:185-196. CrossRef Medline

Hirsch E, Katanaev VL, Garlanda C, Azzolino O, Pirola L, Silengo L, Sozzani S, Mantovani A, Altruda F, Wymann MP (2000) Central role for G protein-coupled phosphoinositide 3-kinase gamma in inflammation. Science 287:1049-1053. CrossRef Medline

Hirsch E, Lembo G, Montrucchio G, Rommel C, Costa C, Barberis L (2006) Signaling through PI3Kgamma: a common platform for leukocyte, platelet and cardiovascular stress sensing. Thromb Haemost 95:29-35. Medline

Hyong A, Jadhav V, Lee S, Tong W, Rowe J, Zhang JH, Tang J (2008) Rosiglitazone, a PPAR gamma agonist, attenuates inflammation after surgical brain injury in rodents. Brain Res 1215:218-224. CrossRef Medline

Jin R, Yang G, Li G (2010a) Inflammatory mechanisms in ischemic stroke: role of inflammatory cells. J Leukoc Biol 87:779-789. CrossRef Medline

Jin R, Yu S, Song Z, Quillin JW, Deasis DP, Penninger JM, Nanda A, Granger DN, Li G (2010b) Phosphoinositide 3-kinase-gamma expression is upregulated in brain microglia and contributes to ischemia-induced microglial activation in acute experimental stroke. Biochem Biophys Res Comm 399:458-464. CrossRef Medline

Jin R, Song Z, Yu S, Piazza A, Nanda A, Penninger JM, Granger DN, Li G (2011) Phosphatidylinositol-3-kinase gamma plays a central role in blood-brain barrier dysfunction in acute experimental stroke. Stroke 42: 2033-2044. CrossRef Medline

Jin Y, Silverman AJ, Vannucci SJ (2009) Mast cells are early responders after hypoxia-ischemia in immature rat brain. Stroke 40:3107-3112. CrossRef Medline

Kim DI, Kim SR, Kim HJ, Lee SJ, Lee HB, Park SJ, Im MJ, Lee YC (2012) PI3K-gamma inhibition ameliorates acute lung injury through regulation of IkappaBalpha/NF-kappaB pathway and innate immune responses. J Clin Immunol 32:340-351. CrossRef Medline

Kobayashi N, Ueki K, Okazaki Y, Iwane A, Kubota N, Ohsugi M, Awazawa M, Kobayashi M, Sasako T, Kaneko K, Suzuki M, Nishikawa Y, Hara K, Yoshimura K, Koshima I, Goyama S, Murakami K, Sasaki J, Nagai R, Kurokawa M, et al. (2011) Blockade of class IB phosphoinositide-3 kinase ameliorates obesity-induced inflammation and insulin resistance. Proc Natl Acad Sci U S A 108:5753-5758. CrossRef Medline

Krafft PR, McBride DW, Lekic T, Rolland WB, Mansell CE, Ma Q, Tang J, Zhang JH (2014) Correlation between subacute sensorimotor deficits and brain edema in two mouse models of intracerebral hemorrhage. Behav Brain Res 264:151-160. CrossRef Medline

Kuo A, Smith MT (2014) Theoretical and practical applications of the intracerebroventricular route for CSF sampling and drug administration in CNS drug discovery research: a mini review. J Neurosci Methods 233: 166-171. CrossRef Medline

Laffargue M, Calvez R, Finan P, Trifilieff A, Barbier M, Altruda F, Hirsch E, Wymann MP (2002) Phosphoinositide 3-kinase gamma is an essential amplifier of mast cell function. Immunity 16:441-451. CrossRef Medline

Ling C, Sandor M, Fabry Z (2003) In situ processing and distribution of intracerebrally injected OVA in the CNS. J Neuroimmunol 141:90-98. CrossRef Medline

Liu L, Puri KD, Penninger JM, Kubes P (2007) Leukocyte PI3Kgamma and PI3Kdelta have temporally distinct roles for leukocyte recruitment in vivo. Blood 110:1191-1198. CrossRef Medline

Lo W, Bravo T, Jadhav V, Titova E, Zhang JH, Tang J (2007) NADPH oxidase inhibition improves neurological outcomes in surgically-induced brain injury. Neurosci Lett 414:228-232. CrossRef Medline

Ma Q, Manaenko A, Khatibi NH, Chen W, Zhang JH, Tang J (2011) Vascular adhesion protein-1 inhibition provides antiinflammatory protection after an intracerebral hemorrhagic stroke in mice. J Cereb Blood Flow Metab 31:881-893. CrossRef Medline

Manninen PH, Raman SK, Boyle K, el-Beheiry H (1999) Early postoperative complications following neurosurgical procedures. Can J Anaesth 46: 7-14. CrossRef Medline

Martin EL, Souza DG, Fagundes CT, Amaral FA, Assenzio B, Puntorieri V, Del Sorbo L, Fanelli V, Bosco M, Delsedime L, Pinho JF, Lemos VS, Souto FO, Alves-Filho JC, Cunha FQ, Slutsky AS, Rückle T, Hirsch E, Teixeira MM, Ranieri VM (2010) Phosphoinositide-3 kinase gamma activity contributes to sepsis and organ damage by altering neutrophil recruitment. Am J Resp Crit Care Med 182:762-773. CrossRef Medline

Passos GF, Figueiredo CP, Prediger RD, Silva KA, Siqueira JM, Duarte FS, Leal PC, Medeiros R, Calixto JB (2010) Involvement of phosphoinositide 3-kinase gamma in the neuro-inflammatory response and cognitive impairments induced by beta-amyloid $1-40$ peptide in mice. Brain Behav Immun 24:493-501. CrossRef Medline

Patrucco E, Notte A, Barberis L, Selvetella G, Maffei A, Brancaccio M, Marengo S, Russo G, Azzolino O, Rybalkin SD, Silengo L, Altruda F, Wetzker R, Wymann MP, Lembo G, Hirsch E (2004) PI3Kgamma modulates the cardiac response to chronic pressure overload by distinct kinase-dependent and -independent effects. Cell 118:375-387. CrossRef Medline

Perino A, Ghigo A, Ferrero E, Morello F, Santulli G, Baillie GS, Damilano F, Dunlop AJ, Pawson C, Walser R, Levi R, Altruda F, Silengo L, Langeberg LK, Neubauer G, Heymans S, Lembo G, Wymann MP, Wetzker R, Houslay MD, et al. (2011) Integrating cardiac PIP3 and cAMP signaling through a PKA anchoring function of p110gamma. Mol Cell 42:84-95. CrossRef Medline

Pomel V, Klicic J, Covini D, Church DD, Shaw JP, Roulin K, BurgatCharvillon F, Valognes D, Camps M, Chabert C, Gillieron C, Françon B, Perrin D, Leroy D, Gretener D, Nichols A, Vitte PA, Carboni S, Rommel C, Schwarz MK, et al. (2006) Furan-2-ylmethylene thiazolidinediones as novel, potent, and selective inhibitors of phosphoinositide 3-kinase gamma. J Med Chem 49:3857-3871. CrossRef Medline

Puri KD, Doggett TA, Huang CY, Douangpanya J, Hayflick JS, Turner M, Penninger J, Diacovo TG (2005) The role of endothelial PI3Kgamma activity in neutrophil trafficking. Blood 106:150-157. CrossRef Medline

Rhodes J (2011) Peripheral immune cells in the pathology of traumatic brain injury? Curr Opin Crit Care 17:122-130. CrossRef Medline

Rickert P, Weiner OD, Wang F, Bourne HR, Servant G (2000) Leukocytes navigate by compass: roles of PI3Kgamma and its lipid products. Trends Cell Biol 10:466-473. CrossRef Medline 
Rommel C, Camps M, Ji H (2007) PI3K delta and PI3K gamma: partners in crime in inflammation in rheumatoid arthritis and beyond? Nat Rev Immunol 7:191-201. CrossRef Medline

Rückle T, Schwarz MK, Rommel C (2006) PI3Kgamma inhibition: towards an 'aspirin of the 21st century'? Nat Rev Drug Discov 5:903-918. CrossRef Medline

Sasaki T, Irie-Sasaki J, Jones RG, Oliveira-dos-Santos AJ, Stanford WL, Bolon B, Wakeham A, Itie A, Bouchard D, Kozieradzki I, Joza N, Mak TW, Ohashi PS, Suzuki A, Penninger JM (2000) Function of PI3Kgamma in thymocyte development, T cell activation, and neutrophil migration. Science 287:1040-1046. CrossRef Medline

Schmidt C, Schneble N, Müller JP, Bauer R, Perino A, Marone R, Rybalkin SD, Wymann MP, Hirsch E, Wetzker R (2013) Phosphoinositide 3-kinase gamma mediates microglial phagocytosis via lipid kinase-independent control of cAMP. Neuroscience 233:44-53. CrossRef Medline

Serezani CH, Ballinger MN, Aronoff DM, Peters-Golden M (2008) Cyclic AMP: master regulator of innate immune cell function. Am J Respir Cell Mol Biol 39:127-132. CrossRef Medline

Smith DF, Deem TL, Bruce AC, Reutershan J, Wu D, Ley K (2006) Leukocyte phosphoinositide- 3 kinase $\{$ gamma $\}$ is required for chemokine-induced, sustained adhesion under flow in vivo. J Leukoc Biol 80:1491-1499. CrossRef Medline

Smith LD, Hickman ES, Parry RV, Westwick J, Ward SG (2007) PI3Kgamma is the dominant isoform involved in migratory responses of human T lymphocytes: effects of ex vivo maintenance and limitations of non-viral delivery of siRNA. Cell Signal 19:2528-2539. CrossRef Medline

Solaroglu I, Beskonakli E, Kaptanoglu E, Okutan O, Ak F, Taskin Y (2004) Transcortical-transventricular approach in colloid cysts of the third ven- tricle: surgical experience with 26 cases. Neurosurg Rev 27:89-92. CrossRef Medline

Stokely ME, Orr EL (2008) Acute effects of calvarial damage on dural mast cells, pial vascular permeability, and cerebral cortical histamine levels in rats and mice. J Neurotrauma 25:52-61. CrossRef Medline

Strbian D, Tatlisumak T, Ramadan UA, Lindsberg PJ (2007) Mast cell blocking reduces brain edema and hematoma volume and improves outcome after experimental intracerebral hemorrhage. J Cereb Blood Flow Metab 27:795-802. Medline

Thomas MS, Mitchell JS, DeNucci CC, Martin AL, Shimizu Y (2008) The pl10gamma isoform of phosphatidylinositol 3-kinase regulates migration of effector CD4 $\mathrm{T}$ lymphocytes into peripheral inflammatory sites. J Leukoc Biol 84:814-823. CrossRef Medline

van Dop WA, Marengo S, te Velde AA, Ciraolo E, Franco I, ten Kate FJ, Boeckxstaens GE, Hardwick JC, Hommes DW, Hirsch E, van den Brink GR (2010) The absence of functional PI3Kgamma prevents leukocyte recruitment and ameliorates DSS-induced colitis in mice. Immunol Lett 131:33-39. CrossRef Medline

Venable JD, Ameriks MK, Blevitt JM, Thurmond RL, Fung-Leung WP (2010) Phosphoinositide 3-kinase gamma (PI3Kgamma) inhibitors for the treatment of inflammation and autoimmune disease. Recent Pat Inflamm Allergy Drug Discov 4:1-15. CrossRef Medline

Yamaguchi M, Jadhav V, Obenaus A, Colohan A, Zhang JH (2007) Matrix metalloproteinase inhibition attenuates brain edema in an in vivo model of surgically-induced brain injury. Neurosurgery 61:1067-1075; discussion 1075-1066. CrossRef Medline

Zhuang X, Silverman AJ, Silver R (1996) Brain mast cell degranulation regulates blood-brain barrier. J Neurobiol 31:393-403. CrossRef Medline 